\title{
Isotopic evidence of strong reliance on animal foods and dietary heterogeneity among Early-Middle Neolithic communities of Iberia
}

\author{
Teresa Fernández-Crespo ${ }^{1,2}$ (I) $\cdot$ Rick J. Schulting ${ }^{1} \cdot$ Javier Ordoño $^{3} \cdot$ Manuel A. Rojo-Guerra ${ }^{4} \cdot$ Jesús Sesma-Sesma $^{5}$. \\ Jesús García-Gazólaz ${ }^{5} \cdot$ Jesús Altuna $^{6} \cdot$ Koro Mariezkurrena $^{6} \cdot$ Pablo Arias $^{7}$
}

Received: 30 June 2018 / Accepted: 17 June 2019 / Published online: 3 July 2019

(C) The Author(s) 2019

\begin{abstract}
Stable carbon and nitrogen isotope research on past populations in the Iberian Neolithic has emphasized the Atlantic and Mediterranean coasts. This study provides the first isotopic insights into the diet and subsistence economy of Early and Middle Neolithic populations from open-air sites in interior north-central Iberia. We present bone collagen carbon $\left(\delta^{13} \mathrm{C}\right)$ and nitrogen $\left(\delta^{15} \mathrm{~N}\right)$ isotope ratios for 44 humans and 33 animals recovered from six cemeteries of the Ebro valley and the northern Iberian Plateau. The results obtained are consistent with the $C_{3}$ terrestrial diets typical of other contemporary south-western European populations, but the spacing between human and herbivore values from Los Cascajos and Paternanbidea sites is higher than expected, and a significant positive correlation is identified between the $\delta^{13} \mathrm{C}$ and $\delta^{15} \mathrm{~N}$ human values at both. Moreover, the results clearly differ from those of the Late Neolithic/Early Chalcolithic in the same region, which show significantly lower $\delta^{13} \mathrm{C}$ and $\delta^{15} \mathrm{~N}$ values. These findings contribute to an understanding of the implementation of an agro-pastoral economy in interior Iberia, suggesting a stronger reliance on animal foods among the first Neolithic groups of inner Iberia than in subsequent periods as well as differential access to some resources (possibly suckling herbivores) in the diet, which may point to the existence of early social or economic inequalities that do not seem to be linked to age and sex parameters or to mortuary treatment.
\end{abstract}

Keywords Subsistence $\cdot$ Stable isotopes $\cdot$ Carbon $\cdot$ Nitrogen $\cdot$ Socioeconomic inequality $\cdot$ Early-Middle Neolithic $\cdot$ Interior Iberian Peninsula

\section{Introduction}

Stable isotope-based palaeodietary reconstructions have made a series of important contributions to the study of European Neolithic subsistence and the dietary changes associated with the adoption of an agro-pastoral economy. They have played a pivotal role in challenging notions of a gradual uptake of domesticated resources, identifying a marked shift from marine to terrestrial diets along the Atlantic coastline coinciding with the Mesolithic-
Electronic supplementary material The online version of this article (https://doi.org/10.1007/s12520-019-00889-2) contains supplementary material, which is available to authorized users.

Teresa Fernández-Crespo

teresa.fernandez-crespo@arch.ox.ac.uk

1 School of Archaeology, University of Oxford, 1 South Parks Road, Oxford OX1 3TG, UK

2 Department of Genetics, Physical Anthropology and Animal Physiology, University of the Basque Country (UPV/EHU), Barrio Sarriena s/n, 48940 Leioa, Spain

3 Department of Archaeology and New Technologies, Arkikus, Pedro de Asúa 63, 01008 Vitoria-Gasteiz, Spain
4 Department of Prehistory and Archaeology, University of Valladolid, Plaza del Campus s/n, 47011 Valladolid, Spain

5 Dirección General de Cultura, Gobierno de Navarra, Pamplona, Spain

6 Arkaios Investigaciones, Mendigain 30, 20014 Donostia-San Sebastián, Spain

7 International Institute for Prehistoric Research of Cantabria (IIIPC), University of Cantabria, Government of Cantabria, Avenida de los Castros s/n, 39005 Santander, Spain 
Neolithic transition (Richards et al. 2003; Schulting 2013). Equally stable isotope analysis has also been used to confront the idea of dietary homogeneity across Europe, of a single Neolithic way of life (Hedges et al. 2013; Raemaekers 2014; Schulting 2018).

North-central Iberia holds one of the largest Early and Middle Neolithic skeletal populations found in Spain. Their analysis provides an invaluable source for understanding the adoption of a new subsistence economy in the region. Here we present a stable isotope dataset of 44 human and 33 animal remains from six funerary sites, located in the mid-upper Ebro valley (Los Cascajos, Paternanbidea, Llano del Montico and La Lámpara), which constitutes an important corridor for the spread of the Neolithic from the Mediterranean coast into the interior of the Peninsula (Bernabeu et al. 2015; Isern et al. 2017), and the northern Iberian Plateau (Molino de Arriba and Fuente Celada) (Fig. 1). A large number of the human individuals included in the study (23 of 44 ) have been directly AMS ${ }^{14} \mathrm{C}$ dated (Fig. 2), providing good chronological control, and the faunal remains are closely associated with the burials. The results, the first to be reported for the Early and Middle Neolithic open-air sites of these regions, are discussed in the context of dietary adaptations in the wider Iberian record.

\section{Neolithization and open-air sites in north- central Iberia}

Open-air settlements are a key feature in the Early and Middle Neolithic record of north-central Iberia (6th-4th millennia cal. $\mathrm{BC})$. The fact that they were generally situated on or near wetlands, endorheic depressions and shores of lakes, lagoons or marshes, favouring both arable plots and pastures has prompted the suggestion of a 'leapfrog colonization' by small Neolithic groups targeting optimal biotopes in the region (Bernabeu et al. 2015; García-Martínez de Lagrán 2015, 2018). These incoming pioneers would have arrived at the Iberian Peninsula around the mid-6th millennium and interacted with local Mesolithic groups, generating new communities that in turn contributed to the spread of farming across the region in the following centuries (Rojo-Guerra et al. 2008; Alday 2012; Rojo-Guerra et al. 2016). Although the contributions of indigenous groups in the process must not be underestimated (Utrilla et al. 1998; Alday 2005), nDNA and mtDNA sequences now available for Iberia show a clear separation in the ancestry of Holocene hunter-gatherers and that of Neolithic population (Gamba et al. 2012; SánchezQuinto et al. 2012; Hervella et al. 2014; Olalde et al. 2015; Lazaridis et al. 2016), supporting a greater genetic input of farmers, as observed across Europe.

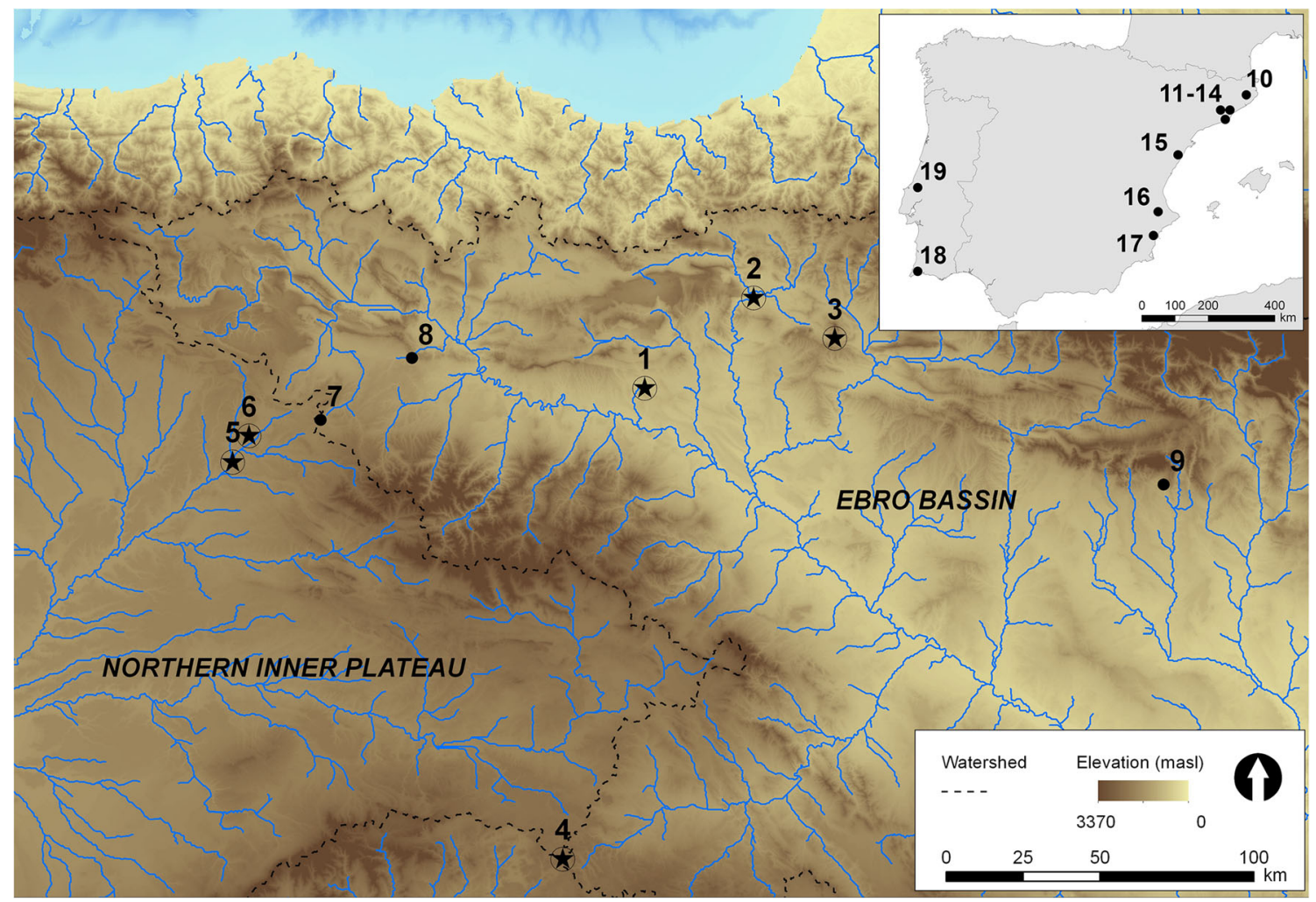

Fig. 1 Map showing the location of the study area in north-central Spain, with reference to the archaeological sites mentioned in the text: (1) Los Cascajos; (2) Paternanbidea; (3) Llano del Montico; (4) La Lámpara; (5) Molino de Arriba; (6) Fuente Celada; (7) Alto de Rodilla; (8) El Prado; (9)
Chaves; (10) Puig d'en Roca; (11) Horts de Can Torras; (12) Can Roqueta-Can Revella; (13) Can Gambús; (14) La Bòbila Madurell; (15) Costamar; (16) Cova de la Sarsa; (17) Tossal de les Basses; (18) Castelo Belinho; (19) Cadaval 
Fig. 2 Bayesian model of the radiocarbon dates available for the human burials of the six Early and Middle Neolithic northcentral Iberian sites under study. Radiocarbon dates include those in the published literature (RojoGuerra and Kunst 1999; GarcíaGazólaz and Sesma-Sesma 2007; Palomino et al. 2011; SesmaSesma et al. 2009; Alameda et al. 2011), recent measurements obtained from Llano del Montico, Molino de Arriba and Los Cascajos (Rojo-Guerra et al. 2016; Fernández-Crespo et al. 2019) and unpublished results from Paternanbidea. The periods have been modelled as simple phases with single boundaries using OxCal4.2 (Bronk Ramsey 2009; Reimer et al. 2013)

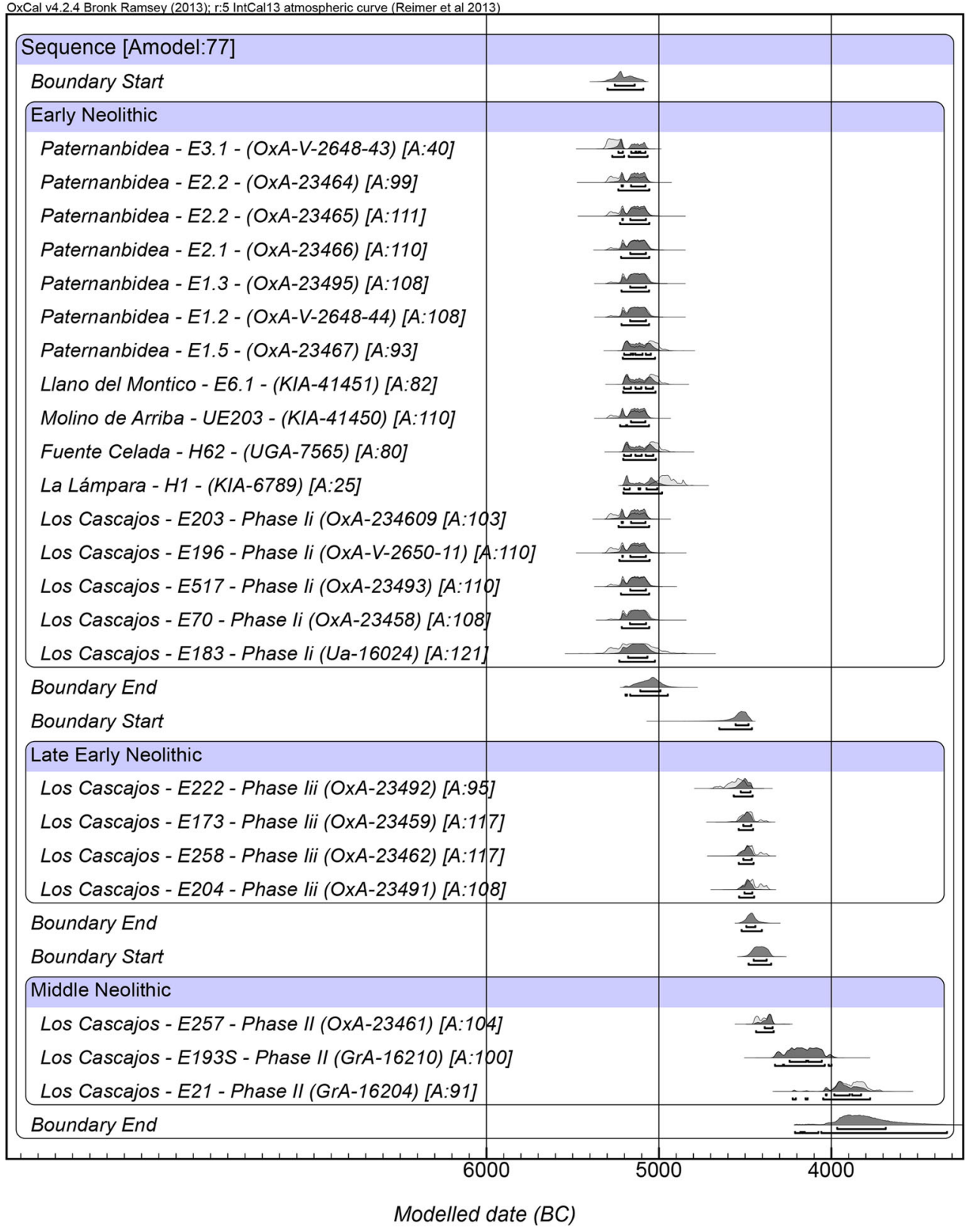

Within the context of Holocene climatic fluctuations, the Early-Middle Neolithic period in north-central Iberia experienced a Continental or Continental/Mediterranean temperate phase, with a landscape dominated by meso-thermophilic mixed forests, principally composed of hazel, birch and to a lesser degree oak, and some shrubs together with humid meadows (Rofes et al. 2013). The emergence of anthropogenic pastures, supported by the presence of nitrophilous species and coprophilous fungi in the palynological records, has been interpreted as a progressive depletion of forests and their substitution by open areas (Fernández-Eraso et al. 2015; PérezDíaz et al. 2015). The available local palaeobotanical record shows the cultivation of naked and hulled varieties of both wheat (emmer: Triticum dicoccum; einkorn: Triticum monococcum; bread wheat: Triticum aestivum/durum) and barley (Hordeum vulgare), while legumes such as lentil (Lens culinaris), bitter and common vetch (Vicia ervilia/ sativa), and other typically early Neolithic domesticates, such as flax (Linum usitatissimum) or opium poppy (Papaver somniferum), are almost absent (Zapata et al. 2004; Stika 2005; Iriarte 2009). The main evidence for the exploitation of wild plants comes from hazelnut (Corylus avellana) shells and acorn (Quercus sp.) cotyledons. Although relatively less abundant, fruit remains, such as crab apple (Malus sylvestris), whitebeam, wild service tree or rowan (Sorbus sp.), dogwood (Cornus sanguinea) and wild grape (Vitis sp.), have also been identified (Zapata 2000; Peña-Chocarro et al. 2005; PeñaChocarro et al. 2013). Moreover, some nearby Cantabrian 
sites highlight the importance of wild plant exploitation not only as potential food but also for medicinal, fuel and technological uses (Cubas et al. 2016).

As regards animal husbandry, the evidence in open-air settlements of the mid-upper Ebro valley displays a clear predominance of cattle, followed by domestic ovicaprines, swine and a few wild animals (mainly red deer, roe deer, horse and wild boar) (e.g. La Renke (Altuna and Mariezkurrena 2001), Los Cascajos (Altuna and Mariezkurrena 2009)). By contrast, caves and rockshelters of the region either do not have domestic livestock, suggesting their use as logistical hunting camps (e.g. Mendandia (Castaños 2005)), or their faunal record is dominated by ovicaprines, suggesting their use as pens (e.g. Chaves (Castaños 2004), Los Husos II (Polo and Fernández-Eraso 2008), Els Trocs (Rojo-Guerra et al. 2013)). But, even in the latter case, caves and rockshelters usually show a notable exploitation of wild ungulates (Altuna 1980), especially deer (e.g. Peña Larga (Castaños 1997), Chaves (Castaños 2004)). In the open-air settlements of the northern Iberian Plateau, however, the large number of remains of domestic sheep and goat (in comparison with those of cattle) found suggests that ovicaprid flocks would have played a major role in the economy of this region (e.g. La Lámpara, La Revilla (Montero and Liesau 2008; García-Martínez de Lagrán 2012)).

Together with open-air sites, pit-grave cemeteries have been considered an important feature of the Early and Middle Neolithic in Iberia (Rojo-Guerra et al. 2016), though caves are also used for burial (e.g. Chaves (Utrilla et al. 2008)) or ritualized skeletal deposits (e.g. Els Trocs (Rojo-Guerra et al. 2013)).

The exceptional collection of pit graves at Los Cascajos (Navarre) was found within an impressive Neolithic open-air settlement. Excavations uncovered a wide range of features, including post-holes for oval or circular huts/houses and fences for enclosing livestock, storage and combustion structures, enclosures and burial pits. A total of 36 individuals, with a predominance of adult and juvenile males (64\%), were recovered from 30 single and three double graves grouped in a cemetery comprising 22 graves, with the remaining 11 graves found scattered across the site (García-Gazólaz and Sesma-Sesma 2007). Skeletons were normally laid out in lateral $(60 \%)$ and supine (30\%) positions and facing SE-SW. Grave goods were generally scarce and, when present, consisted of pottery vessels, flint tools, milling stones, polished axes and shell and bone beads. The presence of domestic fauna, wheat and barley, as well as grinding stones and storage features, confirms the agrarian nature of the settlement (García-Gazólaz and Sesma-Sesma 2001; Peña-Chocarro et al. 2005). Available archaeological data and radiocarbon dates indicate two different Neolithic phases of funerary use: the earliest, phase I, belongs to the Early Neolithic and is divided into two subphases, one spanning 5300-5000 cal. BC (subphase Ii) and the other 4650-4400 cal. BC (subphase lii), whereas the latest or phase II is attributed to the Middle Neolithic, $4200-3500$ cal. BC (Fernández-Crespo et al. 2019) (cf. Fig. 2).
Paternanbidea (Navarre) is another important cemetery located some $45 \mathrm{~km}$ from Los Cascajos with a single Early Neolithic phase of funerary use dated to the late 6th millennium cal. BC (ca. 5300-5000 cal. BC). It held a minimum of 13 individuals in three double graves and one multiple pit grave grouped in an area of $50 \mathrm{~m}^{2}$ (García-Gazólaz 2007). There is a clear predominance of adults ( $85 \%$ ) but more parity between the sexes (four males vs. three females and two probable females). Skeletons, when articulated, were in supine (38\%) or lateral $(15 \%)$ positions and facing SE-NW, E-W or NE-SW. Grave goods are rich, particularly in pendants and shells, bone and green stone beads for necklaces and bracelets, together with some pottery bowls, geometric microliths, flint blades and rock crystal prisms. Very limited faunal remains were recovered, though the excavation did not extend to a possible settlement area.

In addition, a number of Early Neolithic burials exhibiting similar funerary patterns have been documented in northcentral Iberia. The majority has been excavated as a result of rescue campaigns and, despite belonging to potential open-air settlements or necropolises of different sizes, usually only one or two pit graves have been identified. This is the case with Llano del Montico in Navarre (Rojo-Guerra et al. 2016); Molino de Arriba (Palomino et al. 2011), Fuente Celada (Alameda et al. 2011), El Prado (Alonso and Jiménez 2014) and Alto de Rodilla (Alonso and Jiménez 2015) in Burgos; and La Lámpara (Rojo-Guerra and Kunst 1999) in Soria. The interred are usually adults ( 7 of 8 ) of both sexes (4 males, 3 females), laid out in mainly lateral or supine positions, facing preferentially SE and with scarce grave goods (Rojo-Guerra et al. 2016). The principal exception is La Lámpara, interpreted as a storage structure repurposed as a tomb, in which a mature woman was buried together with an elaborately decorated ceramic bottle and a flint blade. Also found in the tomb were 246 pottery fragments, 92 flint elements, three bone tools and a few faunal remains, suggesting a relatively complex funeral ceremony (Rojo-Guerra et al. 2008).

\section{Material and methods}

A total of 50 human samples were selected for analysis. They derive from Los Cascajos $(n=35)$, Paternanbidea $(n=10)$, Llano del Montico $(n=2)$, Fuente Celada $(n=1)$, Molino de Arriba $(n=1)$ and La Lámpara $(n=1)$. Skeletal remains are relatively well preserved, although some were found partially commingled and fragmented due to different taphonomic processes as well as to ritual practices. In the case of multiple graves, sampling was carried out ensuring that each sample corresponded to a unique individual.

In addition, 38 faunal samples from terrestrial herbivores and omnivores were included in the study to ascertain variability in baseline isotopic signatures in the region. They were closely associated with the human burials (i.e. recovered either 
from the same grave or from other pits dated to the same period) and come from Los Cascajos $(n=27)$, Paternanbidea $(n=10)$ and La Lámpara $(n=1)$. Of these, at least nine are non-adult specimens and another five may show a non-adult isotopic signal since the sample was taken from tooth dentine. The sample size is relatively small and biased towards the two large sites due to the absence of animal remains in most of the small sites.

Samples of between 500 and $800 \mathrm{mg}$ were exclusively taken from bone in humans, and from bone or dentine in fauna. Collagen extraction was carried out following a modified Longin (1971) method as described by Richards and Hedges (1999). Some samples from Los Cascajos and Paternanbidea that had previously been radiocarbon dated underwent a 30-kD ultrafiltration step (Brock et al. 2010). Extracted collagen was measured in duplicate in a Sercon 20/22 continuous flow isotope ratio mass spectrometer coupled with an elemental analyzer at the Research Laboratory for Archaeology and the History of Art, University of Oxford. Analytical precision is $\pm 0.2 \%$ ( $1 \sigma)$ for $\delta^{13} \mathrm{C}$ and $\delta^{15} \mathrm{~N}$ based on repeated analysis of standards. Results were calibrated using a two-point calibration with internal cow and seal bone collagen standards bracketing the range of archaeological samples (cf. Coplen et al. 2006). Collagen quality was assessed according to several preservation criteria: collagen yield $>1 \%, \% \mathrm{C}=30-44 \%, \% N=11-$ 16\% and $\mathrm{C}: \mathrm{N}=2.9-3.6$ (DeNiro 1985; Ambrose 1990; van Klinken 1999; Harbeck and Grupe 2009).

Statistical analyses were performed using IBM SPSS software for Windows v17. Z-scores were initially calculated to detect the presence of outliers. Shapiro-Wilk tests were used to test whether or not the data were normally distributed. Student's $t$ tests were employed to compare means between two sample groups when the data did not depart significantly from a normal distribution, and Mann-Whitney's $U$ test when they did. Finally, Pearson's $r^{2}$ and Spearman's rho coefficients were both used to assess correlations, with the latter being more appropriate for non-linear relationships. A significance level of $\alpha=0.05$ was used for all statistical tests.

\section{Results}

\section{Collagen preservation}

The majority of the human samples analyzed provided wellpreserved collagen according to the abovementioned quality criteria (Tables 1 and 2). However, six samples from Los Cascajos did not yield any collagen, and another three, despite having $\mathrm{C}: \mathrm{N}$ ratios within the accepted range, gave collagen yields lower than $1 \%$. This seems to have had a small but significant impact on $\delta^{13} \mathrm{C}$ values, providing an average of $-19.7 \pm 0.4 \%$ o for these three samples compared with that of $-19.3 \pm 0.3 \%$ ofor the remaining 26 individuals at the site $(t=$
2.22, $\mathrm{df}=27, p=0.035)$. The effects of including or excluding these samples have been considered, and they have been retained in subsequent analyses, since observed differences (a) are relatively small, on the order of $0.5 \%$ or less; (b) do not affect any patterns with regard to age, sex, location or chronology among the individuals; and (c) affect $\delta^{13} \mathrm{C}$ values only, showing no divergences in $\delta^{15} \mathrm{~N}$. Moreover, 13 samples (eight from Los Cascajos, two from Paternanbidea and one each from Llano del Montico, Molino de Arriba and Fuente Celada) exhibit \%C and/or \% $\mathrm{N}$ values slightly below or above the generally accepted limits but have acceptable $\mathrm{C}: \mathrm{N}$ ratios and collagen yields. Since they were found not to substantially alter the results (individual $Z$-scores generally $<1.0$; Student's $t$ tests, $p>0.05$ ), they were also retained. Comparison between samples including the $30-\mathrm{kD}$ ultrafiltration step and those that do not shows no significant difference, which is consistent with previous studies (Hull 2008; Sealy et al. 2014). The faunal collagen quality indicators show more variable preservation, particularly for Los Cascajos, seemingly linked to the considerable taphonomic deterioration documented in the faunal remains (Altuna and Mariezkurrena 2019), which was probably caused by their deposition in relatively shallow features compared with the funerary pits. Five faunal samples yielded $\mathrm{C}: \mathrm{N}$ ratios above 3.6 and were excluded from the analysis. Sixteen samples exhibiting collagen yields, \%C and/or $\% \mathrm{~N}$ values below the generally accepted limits were retained, given that their $\delta^{13} \mathrm{C}$ and $\delta^{15} \mathrm{~N}$ average values proved not to be significantly different from those samples showing acceptable collagen preservation (e.g. $t$ test for Los Cascajos domestic herbivores: $\delta^{13} \mathrm{C}: t=1.05, \mathrm{df}=15, p=0.313 ; \delta^{15} \mathrm{~N}$ : $t=0.28, \mathrm{df}=15, p=0.784)$. In summary, a total of 11 samples were therefore excluded, leaving 44 humans and 33 fauna for further analysis.

\section{Faunal isotope data}

The $\delta^{13} \mathrm{C}$ and $\delta^{15} \mathrm{~N}$ ratios for herbivores and omnivores are consistent with expectations for a temperate $\mathrm{C}_{3}$ ecosystem (DeNiro and Epstein 1978; Schwarcz and Schoeninger 1991) (Table 1). No significant differences are found in $\delta^{13} \mathrm{C}$ and $\delta^{15} \mathrm{~N}$ values between domestic bovines and ovicaprines, providing a combined average of $\delta^{13} \mathrm{C}=-20.6 \pm 0.3 \%$ and $\delta^{15} \mathrm{~N}=5.7 \pm 1.4 \%$ at Los Cascajos and of $\delta^{13} \mathrm{C}=-20.3 \pm$ $0.2 \%$ and $\delta^{15} \mathrm{~N}=5.0 \pm 0.7 \%$ at Paternanbidea. The higher standard deviation for $\delta^{15} \mathrm{~N}$ results is due to the presence of a nursing signal in some samples belonging to immature individuals or being obtained from tooth dentine at Los Cascajos $\left(\delta^{15} \mathrm{~N}\right.$ ca. $6-8 \%$ ), yielding higher values than those of adult specimens, though only in the case of Bovidae does the difference attain statistical significance (Table A.1). The only values for auroch and wild horse are similar to those from adult domestic herbivores. The results for suids, whether wild (wild boar) or domestic (pig), are significantly higher than the 


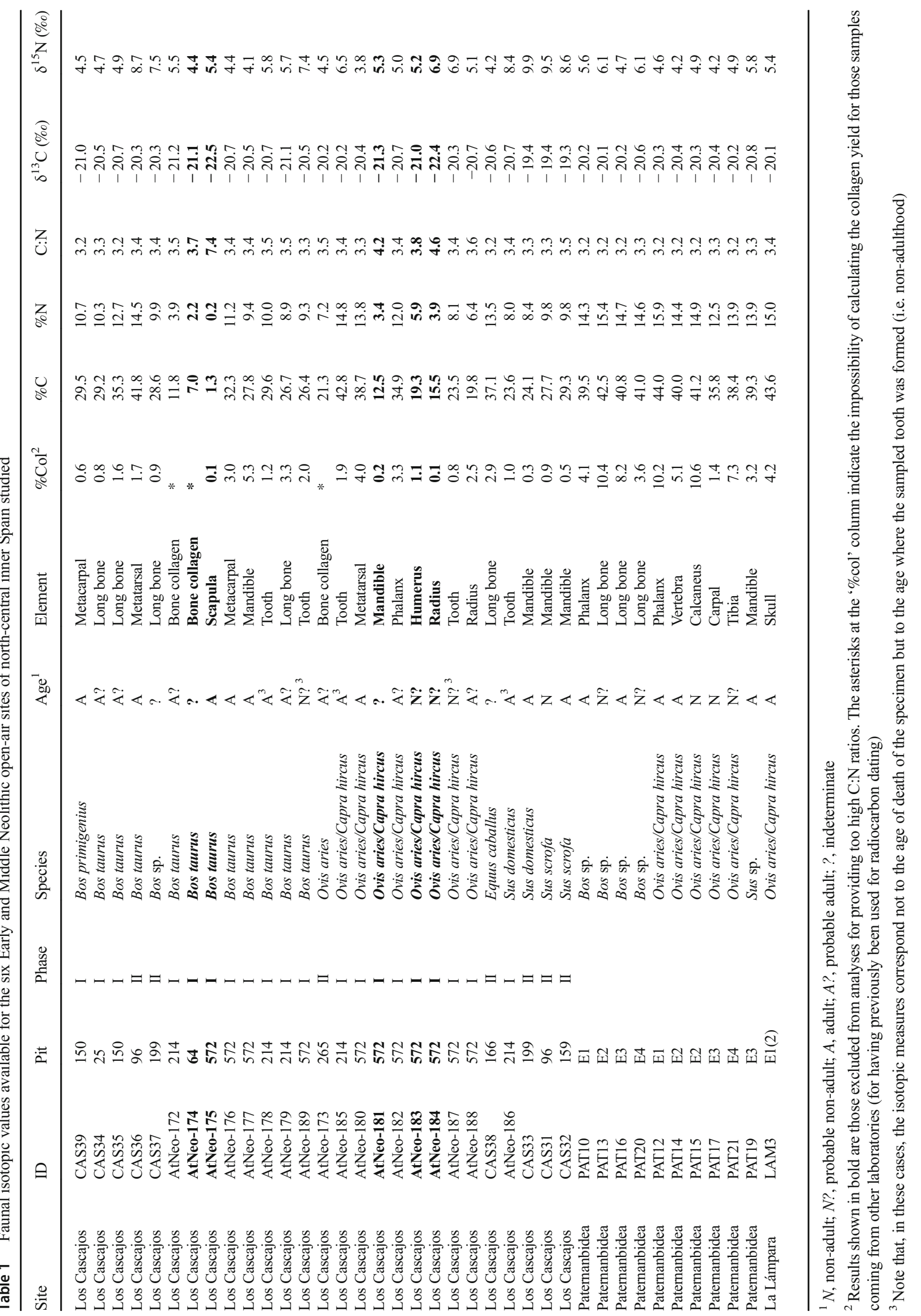




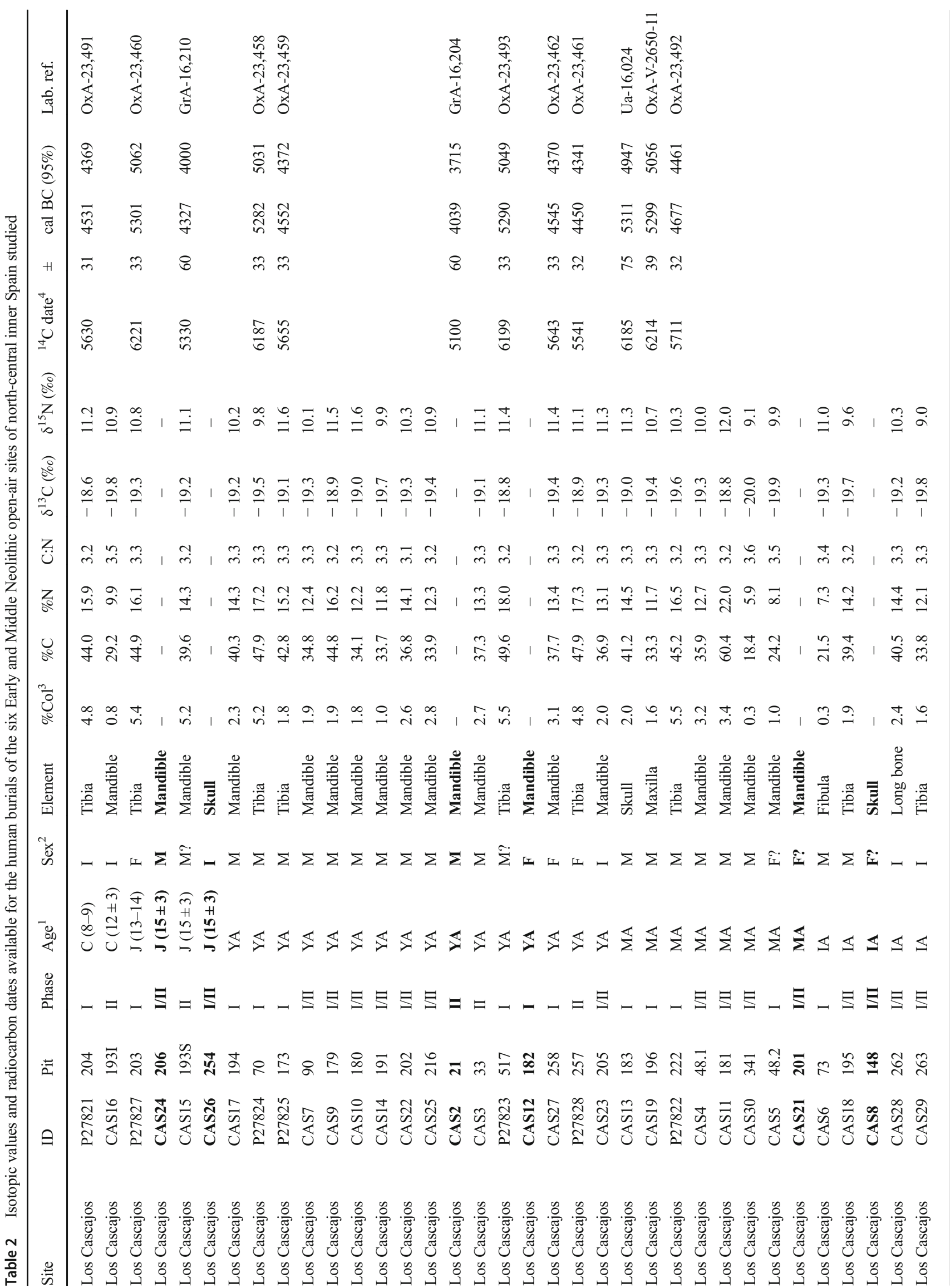




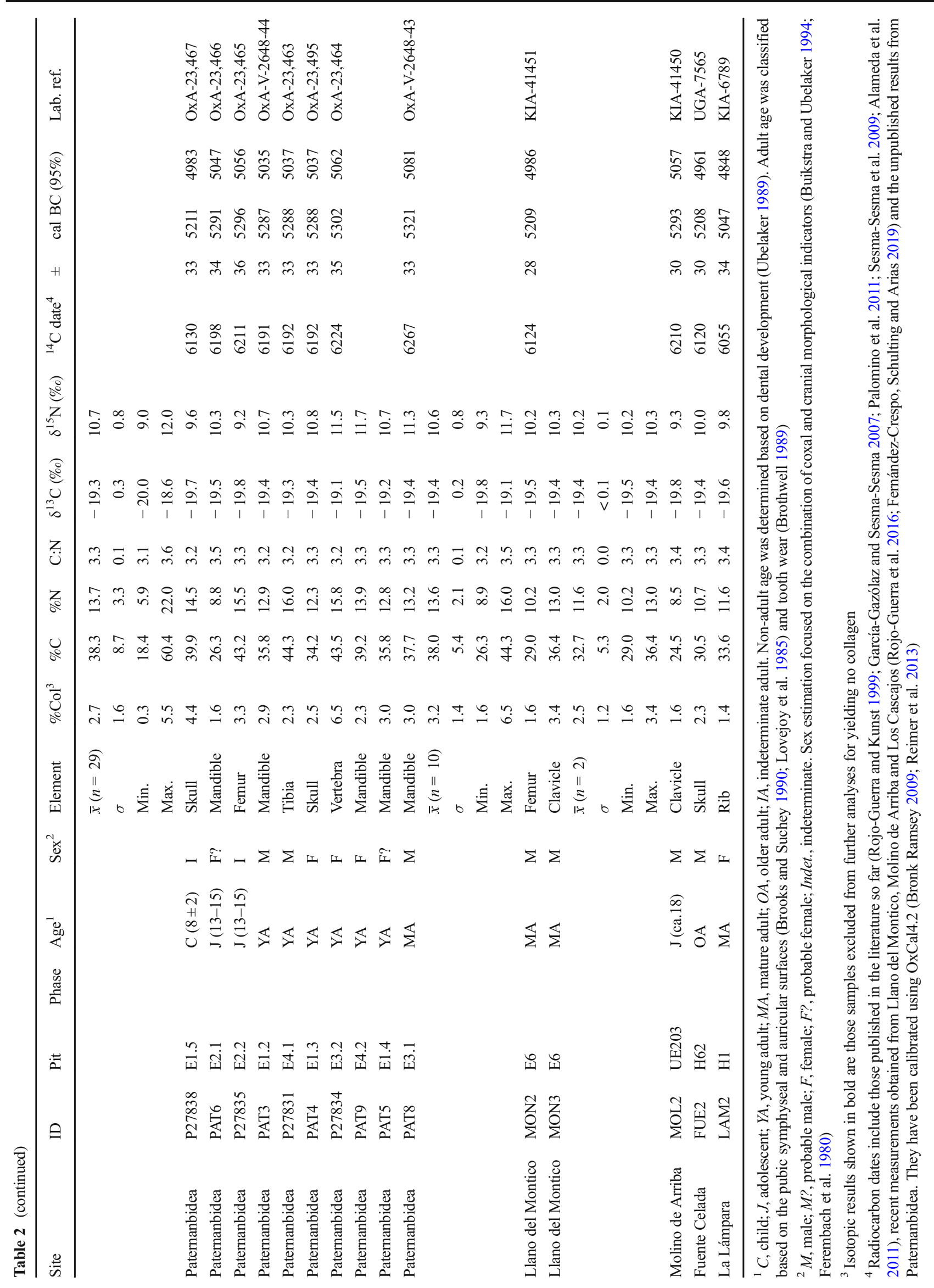


herbivores in both isotopes, as would be expected for an omnivorous diet (e.g. Los Cascajos: $\delta^{13} \mathrm{C} \bar{x}=-19.7 \pm 0.6 \%$; $\delta^{15} \mathrm{~N} \bar{x}=9.1 \pm 0.7 \% 0$ ).

\section{Human isotope data}

The $\delta^{13} \mathrm{C}$ and $\delta^{15} \mathrm{~N}$ human values cluster reasonably tightly (Los Cascajos $(n=29)$ : $\delta^{13} \mathrm{C} \bar{x}=-19.3 \pm 0.3, \delta^{15} \mathrm{~N} \bar{x}=10.7 \pm 0.8$; Paternanbidea $(n=10): \delta^{13} \mathrm{C} \bar{x}=-19.4 \pm 0.2, \delta^{15} \mathrm{~N} \bar{x}=10.6 \pm$ 0.8; Llano del Montico $(n=2): \delta^{13} \mathrm{C} \bar{x}=-19.4 \pm<0.1$, $\delta^{15} \mathrm{~N} \bar{x}=10.2 \pm 0.1$; Molino de Arriba $(n=1): \delta^{13} \mathrm{C}=-19.8$, $\delta^{15} \mathrm{~N}=9.3$; Fuente Celada $(n=1): \delta^{13} \mathrm{C}=-19.4, \delta^{15} \mathrm{~N}=10.0$; La Lámpara $(n=1)$ : $\delta^{13} \mathrm{C}=-19.6, \delta^{15} \mathrm{~N}=9.8$ ) (Table 2). However, there are certain additional aspects that are worth exploring.

Los Cascajos is the only site where the human and faunal results combined with archaeological and chronological data allow an intra-site analysis. That being said, no statistically significant differences are observed with regard to chronology (phases and subphases), location (necropolis or isolated) or type of pit-grave (single or double), body position (lateral or supine) and orientation, or the presence/absence of grave goods (Table A.2), nor are there any differences in the isotopic values concerning the sex of the interred. This is also the case at Paternanbidea, the other site whose sample size allows comparisons in this respect. Grouping the data from all the funerary contexts also reveals no significant sex-based differences (Table A.3). Regarding age, however, Los Cascajos nonadults (8-20 years old) exhibit values that are significantly higher than those of adults in $\delta^{15} \mathrm{~N}(t=2.14, \mathrm{df}=27, p=$ 0.043 ) though not in $\delta^{13} \mathrm{C}$ (Table A.4). This trend is reversed in the nearby site of Paternanbidea, where non-adults show lower values than adults not only in $\delta^{15} \mathrm{~N}(t=3.63, \mathrm{df}=8, p=$ $0.007)$ but also in $\delta^{13} \mathrm{C}(t=3.45, \mathrm{df}=8, p=0.009)$.

Finally, we note the existence of a marked positive correlation between human $\delta^{13} \mathrm{C}$ and $\delta^{15} \mathrm{~N}$ values both at Los
Cascajos $\left(r^{2}=0.521, p<0.001 ;\right.$ rho $\left.=0.768, p<0.001\right)$ and Paternanbidea $\left(r^{2}=0.503, p=0.022\right.$; rho $\left.=0.488, p=0.153\right)$. The correlation at Los Cascajos is also seen in the fauna $\left(r^{2}=\right.$ $0.452, p=0.001$; rho $=0.475, p=0.026$ ) (Fig. 3 ) and persists even when the data are divided into the Early and Middle Neolithic phases. The small sample sizes of the other funerary contexts analyzed prevent the detection (or rejection) of such a correlation.

\section{Discussion}

The human $\delta^{13} \mathrm{C}$ and $\delta^{15} \mathrm{~N}$ values are broadly consistent with $\mathrm{C}_{3}$ plant-based diets typical of the European Neolithic (Hedges et al. 2013; Schulting 2011) (Fig. 4), though this does still leave scope for intra- and inter-site variability. With regard to differences within sites, the only significant findings relate to age. It is possible that higher or lower non-adult $\delta^{15} \mathrm{~N}$ values seen in Los Cascajos and Paternanbidea, respectively, reflect compromised health status due to nutritional deficiencies or infectious diseases (Beaumont and Montgomery 2016), since these children and adolescents did not reach adulthood (cf. the 'Osteological Paradox' (Wood et al. 1992; DeWitte and Stojanowski 2015)). Moreover, it must be considered that bone collagen turnover rates are high in early infancy but decrease over the course of childhood into adolescence (Tsutsaya and Yoneda 2013), hence reflecting different time spans. Thus, periods of stress and starvation would be expected to have much greater isotopic visibility in non-adults than in adults. In any case, both the small samples of non-adults available (four at Los Cascajos and three at Paternanbidea) and the fact that no skeletal evidence for a higher prevalence of disease has been observed among these warrants caution in interpreting the observed isotopic differences. Although variability in climate factors at a local scale may be driving some small inter-site differences in isotopic values, especially with
Fig. 3 Positive correlation between $\delta^{13} \mathrm{C}$ and $\delta^{15} \mathrm{~N}$ values observed in both human and faunal samples at Los Cascajos

\section{LOS CASCAJOS}

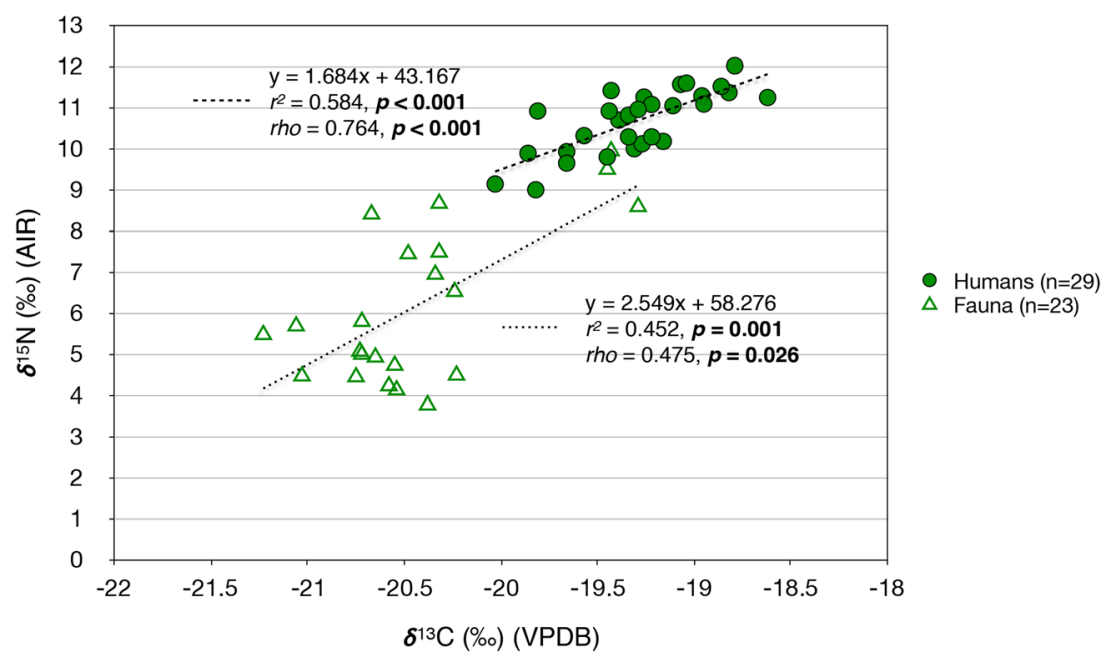


Fig. 4 Dispersion of $\delta^{13} \mathrm{C}$ and $\delta^{15} \mathrm{~N}$ human and faunal values of the sites studied

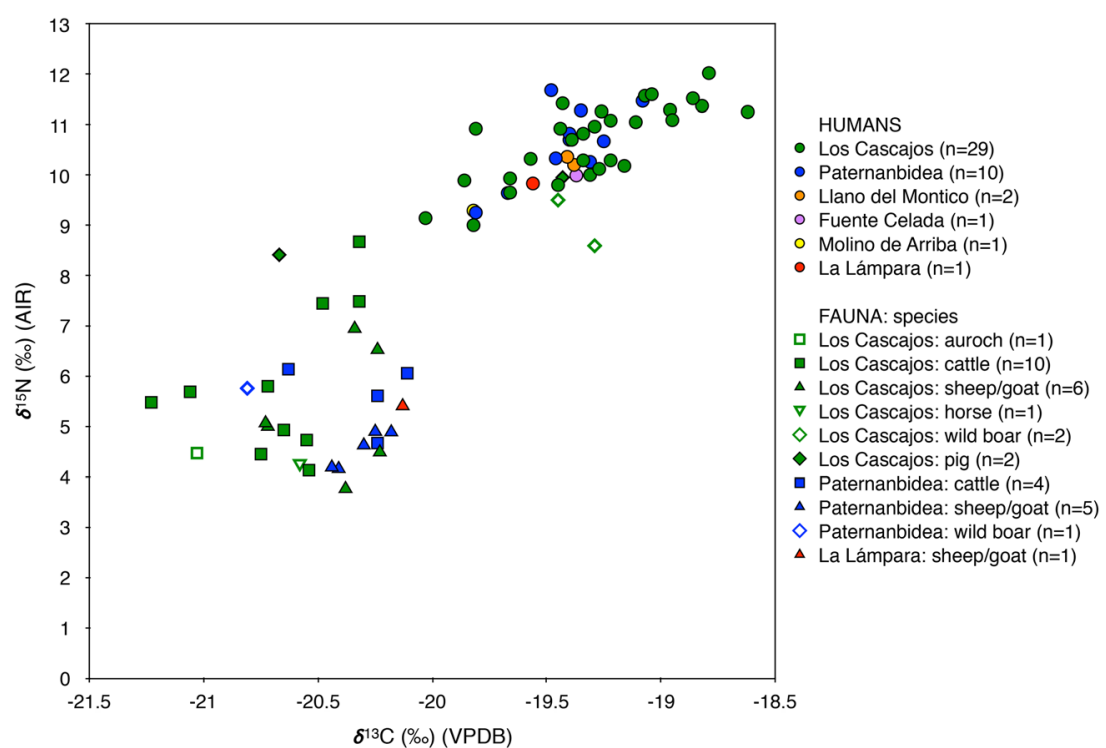

regard to $\delta^{13} \mathrm{C}$ values, where a weak correlation $\left(r^{2}=0.225\right.$, $p=0.142 ;$ rho $=0.321, p=0.039)($ Fig. 5) is seen with present mean annual temperature (Ninyerola et al. 2005), the similarity of the results from the six sites, and from the two periods represented-Early and Middle Neolithic, extending over a millennium - suggests similar dietary and plant/animal management practices. Apart from these considerations, there are three major findings that are worth discussing in detail.

\section{Trophic level offsets between humans and herbivores}

There are relatively consistent offsets between the herbivore terrestrial fauna and human isotope values $\left(\Delta_{\text {human-herbivore }}\right)$ at both Los Cascajos $\left(1.3 \%\right.$ for $\delta^{13} \mathrm{C}$ and $5.2 \%$ for $\left.\delta^{15} \mathrm{~N}\right)$ and Paternanbidea $\left(0.9 \%\right.$ for $\delta^{13} \mathrm{C}$ and $5.6 \%$ for $\left.\delta^{15} \mathrm{~N}\right)$. Comparing these data with those from other Neolithic Iberian major sites, it can be observed that this pattern is not exclusive to the mid-upper Ebro valley, since the site of $\mathrm{La}$ Bòbila Madurell, Catalonia, shows a similar spacing (0.9\%o for $\delta^{13} \mathrm{C}$ and $5.4 \%$ or $\delta^{15} \mathrm{~N}$ ). This may also be the case for the nearby (1 km apart) coeval site of Can Gambús: although faunal isotopic values are lacking there, the spacing with regard to the herbivore values of La Bòbila Madurell is comparable $\left(1.1 \%\right.$ o for $\delta^{13} \mathrm{C}$ and $5.2 \%$ for $\delta^{15} \mathrm{~N}$ ) (Fontanals-Coll et al. 2015). Unfortunately, it is difficult to assess whether or not this pattern is present in other Early-Middle Neolithic Iberian sites given the small sample sizes (e.g. Costamar (Salazar-García 2009), Cova de la Sarsa (Salazar-García 2010), Can Roqueta-Can Revella, Horts de Can Torras (Fontanals-Coll et al. 2017), Cadaval (Guiry et al. 2016), Chaves (Villalba-Mouco et al. 2018a), La Lámpara (this paper)) and/or the absence of fauna in many case-studies (e.g. Castelo Belinho (Carvalho and Petchey 2013), Puid d'en Roca (Gibaja et al. 2017), Tossal de les Basses (SalazarGarcía et al. 2016)).

Assuming the range typically accepted for trophic level enrichments in the archaeological literature (ca. $0.8-1.3 \%$ o for $\delta^{13} \mathrm{C}$ and $3-5 \%$ for $\delta^{15} \mathrm{~N}$ ), the observed humanherbivore shifts of ca. $1 \% \circ \delta^{13} \mathrm{C}$ and ca. $5 \%$ for $\delta^{15} \mathrm{~N}$ would require that terrestrial mammalian fauna contributed essentially $100 \%$ of the protein in the diet. But, of course, this is unlikely given the limited degree to which protein can
Fig. 5 Correlation observed between $\delta^{13} \mathrm{C}$ and $\delta^{15} \mathrm{~N}$ human values obtained at each site and mean annual temperature $\left({ }^{\circ} \mathrm{C}\right)$ (Ninyerola et al. 2005)

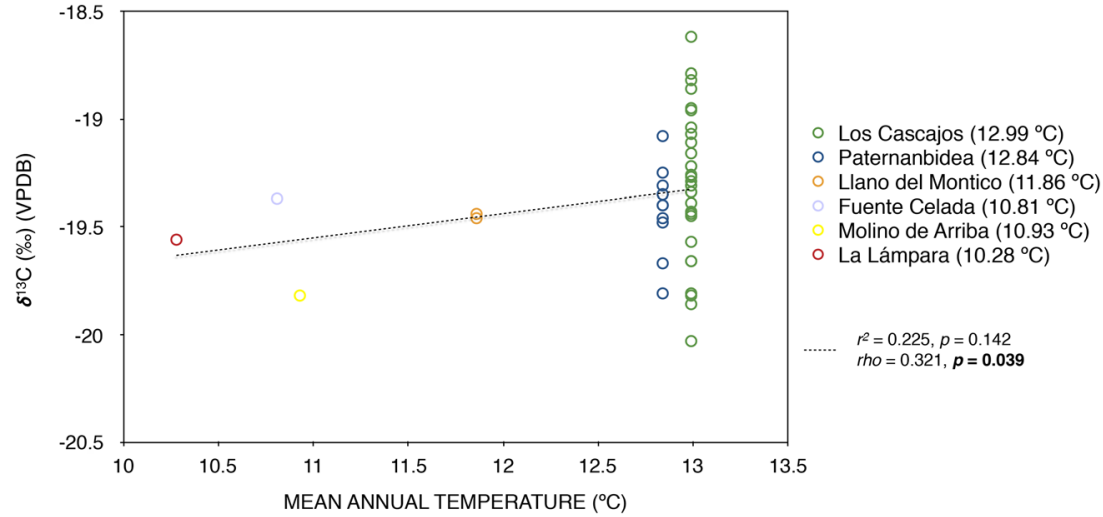


contribute to the body's energy requirements (Speth and Spielmann 1983). The shortfall needs to be made up by lipids and/or carbohydrates, and cereals and other plants would generally contribute significantly lower $\delta^{13} \mathrm{C}$ and $\delta^{15} \mathrm{~N}$ values to human diets. Even assuming a larger offset of ca. $6 \%$ for $\delta^{15} \mathrm{~N}$, as recently proposed by O'Connell et al. (2012), the isotopic values would still require an unusually high animal protein intake for European Neolithic farmers (for comparison, it can be noted that the vast majority of LBK sites from Central Europe never reach such a shift (Hedges et al. 2013)). Therefore, the observed isotopic human-herbivore offsets suggest the regular consumption of other higher trophic level foods underrepresented or missing in the sample studied and/or in the archaeological record. Considering that neither cereals (generally expected to have $\delta^{13} \mathrm{C}$ values ca. $1 \%$ lower than those of herbivores even if $\delta^{15} \mathrm{~N}$ is raised by moderate levels of manuring), nor $\mathrm{C}_{4}$ plants (archaeologically absent anywhere in Iberia at this time (Moreno-Larrazabal et al. 2015)) nor marine foods (given the considerable distance of these sites from the sea, and the absence of any evidence for marine foods) are likely to explain enrichment in both ${ }^{13} \mathrm{C}$ and ${ }^{15} \mathrm{~N}$, two possibilities seem more feasible to us.

First, it is possible that protein intake included a significant proportion of non-adult domestic herbivores (represented by 11 of the 33 successfully measured samples (Table 1)), which show higher $\delta^{13} \mathrm{C}$ and $\delta^{15} \mathrm{~N}$ presumably because of the nursing signal (which would persist for some months even in the flesh in young, fully weaned specimens (Sponheimer et al. 2006)). Unfortunately, the zooarchaeological sample in our sites is too small to assess the extent to which the exploitation of these prevailed in the livestock economy (Altuna and Mariezkurrena 2019; Montero and Liesau 2008). However, the predominance of infant (i.e. nursing) and young (i.e. recently weaned) ovicaprids is seen in the coeval faunal assemblage from Chaves cave, also in the Ebro valley (Castaños 2004). Pigs might also have raised the isotopic values in human consumers due to their omnivorous diet, but based on their limited presence among the ungulates in our sites (Fig. 6) (Table 3), they do not seem to have been a major food source. A second possibility is that the consumption of freshwater resources, which are archaeologically almost absent, was more important than suspected. However, stable carbon isotopes in freshwater aquatic systems, though highly variable, are usually ${ }^{13} \mathrm{C}$-depleted (Dufour et al. 1999), as observed in a study of modern fish from the Flix reservoir on the Ebro river (Soto et al. 2011). The exploitation of migratory birds consuming a mix of freshwater and marine foods and inhabiting the wetlands where the sites are located could also have shifted the human values in the direction observed, but again, their remains have been scarcely archaeologically documented, let alone in the numbers that would be required to make a notable impact on human diets. These two possibilities have also been suggested to explain high protein intake and unusual $\Delta_{\text {human-herbivore }}$ spacing in some central and northern French Neolithic sites (Goude and Fontugne 2016), as well as elsewhere in the European Neolithic (Hedges and Reynard 2007; Hedges et al. 2008). However, the contribution of non-adult domestic animals fits better in the context of Early-Middle Neolithic north-central Spain, given the zooarchaeological evidence. In addition, Bayesian diet modelling using FRUITS (Fernandes et al. 2014) does not suggest any significant role for freshwater resources here (see Appendix B). Although these models do not provide either a definitive answer on the possible nature of the terrestrial food source/s producing the observed $\Delta_{\text {human-herbivore }}$ isotope enrichment, a relatively high consumption of non-adult herbivores remains, in our opinion, as a viable explanation.

The seasonal slaughter of calves and lambs may be seen here as management strategy by Early and Middle Neolithic groups. The culling of nursing animals would have optimized dairy production by removing unwanted surplus (particularly of males) before the animals were weaned, as well as facilitated the future supply of fodder, water and shelter for overwintering animals by controlling herd size. Culling of fully weaned young specimens, by contrast, it is considered to be a practice aimed at promoting meat production (Gillis et al. 2014). Whichever practice predominated in the sites studied, this evidence raises questions about the capacity of these communities to keep the balance between the exploitation of herds and the cost of maintaining them.

\section{Positive correlation between $\delta^{13} \mathrm{C}$ and $\delta^{15} \mathrm{~N}$ human values}

Explaining the significant positive correlation between the human $\delta^{13} \mathrm{C}$ and $\delta^{15} \mathrm{~N}$ values in both phases of Los Cascajos and at Paternanbidea is a separate issue from that of their high trophic level offsets. In a review of the published data, comparable correlations can be found in other Middle Neolithic Iberian open-air sites including Can Gambús $\left(r^{2}=0.113, p=0.035\right.$; rho $=0.303$, $p=0.069$ ) (Fontanals-Coll et al. 2015) and Tossal de les Basses $\left(r^{2}=0.442, p=0.026 ;\right.$ rho $\left.=0.600, p=0.051\right)$ (Salazar-García et al. 2016). A similar trend may apply to other contemporary sites, although the typically small size of the available human sample often precludes statistical testing (Fig. 7).

In other contexts, similar correlations have been found when comparing sites within a region and these have been attributed to environmental factors, specifically precipitation gradients (Hollund et al. 2010). While, as noted above, there are hints that climate is relevant even within the small region encompassed by the present study, the correlation being discussed here is found within sites, rather than between them, so that another explanation is required.

Again, the use of FRUITS agent-based Bayesian models does not resolve the issue, as the results (cf. Appendix B in the 
Fig. 6 Number of identified specimens (NISP), minimum number of individuals (MNI) and meat weight estimation $(\mathrm{mW})$ of the ungulate remains recovered from Los Cascajos, La Lámpara and Chaves Early and Middle Neolithic phases/layers, displayed as percentages (data obtained from Altuna and Mariezkurrena 2019; Montero and Liesau 2008; Castaños 2004, respectively)
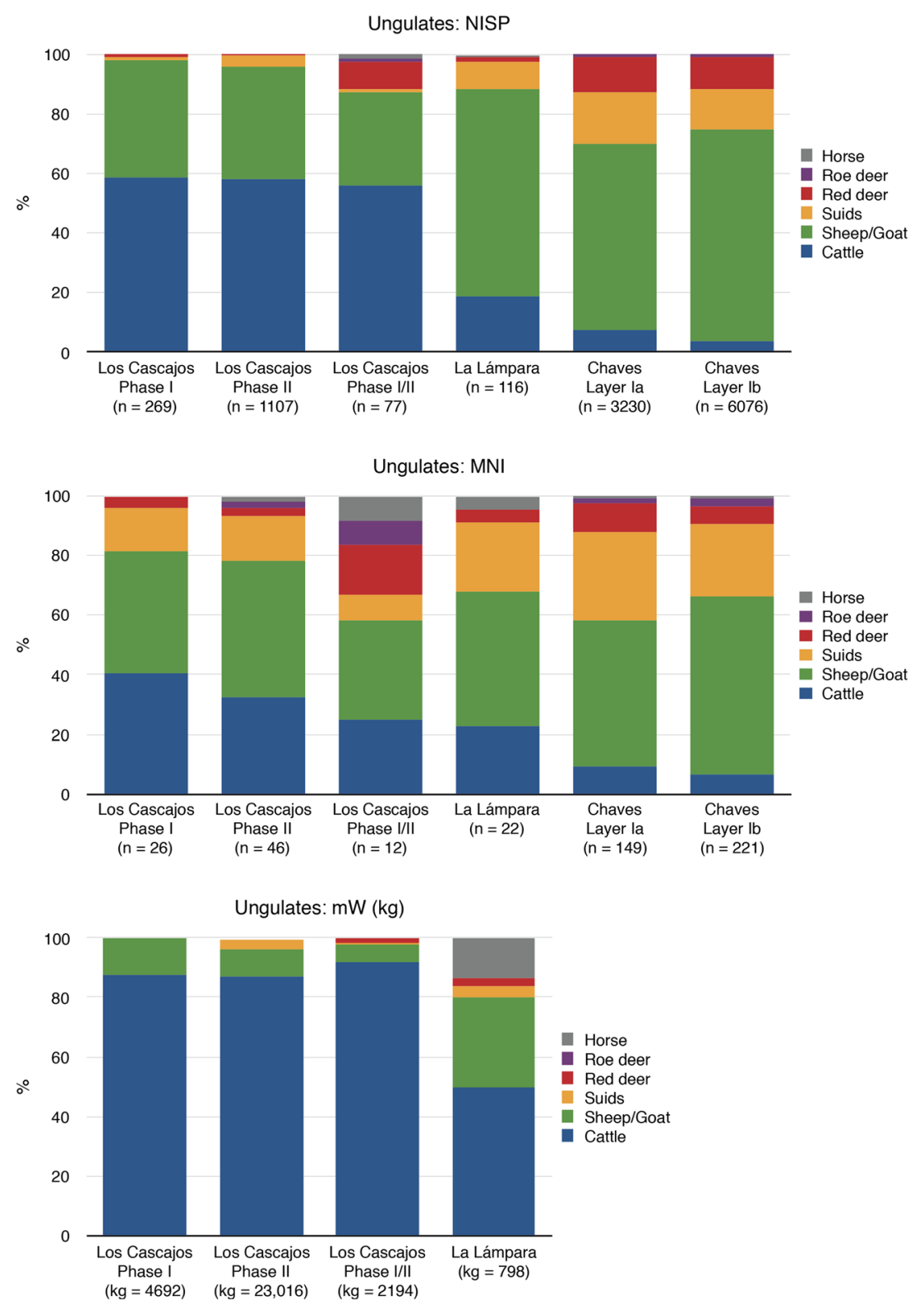

ESM) do not provide any clearer identification of carbon- and nitrogen-enriched terrestrial food source/s producing the observed correlation. The problem here is the relatively small isotopic and nutritional differences between the key food sources (especially adult vs. non-adult herbivores). Each of the food groups is modelled as contributing between 0 and $48 \%$ of the diet (other than cereals - between 32 and $86 \%$ but this is because of the model parameter specifying that no more than $40 \%$ of energy requirements be met by protein). In this case, the model only shows what was already apparent from a consideration of the plotted values, i.e. the existence of differences in the relative proportion of plants and animals consumed between individuals at both extremes of the correlation. What is particularly problematic here is the absence of direct isotopic values for cereals and legumes.
It may be that the higher-trophic-level food source (i.e. non-adult domestic herbivores) behind the human-herbivore spacing played an important role in the creation of the correlations observed. Perhaps a section of the community had a diet emphasizing the consumption of terrestrial animal protein and, in some cases (i.e. those individuals with higher carbon and nitrogen isotopic values), primarily from domesticated nursing or recently weaned herbivores due to their sociopolitical status or, alternatively, to their economic practices.

On the one hand, the slaughter of nursing calves and lambs has been considered to be a far less economical practice than the culling of weaned non-adults and adults for prioritizing dairy over meat production (Saña 2000), and thus might implicate that their consumption was more frequent among the 'elite', assuming that differential access depended on social 
Table 3 Number of identified specimens (NISP), minimum number of individuals (MNI) and, when available, meat weight estimation $(\mathrm{mW})$ of the ungulate remains recovered from Los Cascajos, La Lámpara and
Chaves E/M Neolithic phases (data obtained from Altuna and Mariezkurrena 2019; Montero and Liesau 2008; Castaños 2004, respectively)

\begin{tabular}{|c|c|c|c|c|c|c|c|c|c|c|c|c|c|c|c|c|}
\hline \multirow{3}{*}{$\begin{array}{l}\text { Site } \\
\text { Phase/layer } \\
\text { Species }\end{array}$} & \multicolumn{9}{|c|}{ Los Cascajos } & \multirow{2}{*}{\multicolumn{3}{|c|}{$\begin{array}{l}\text { La Lámpara } \\
\text { Pit no. } 1\end{array}$}} & \multicolumn{4}{|c|}{ Chaves } \\
\hline & \multicolumn{3}{|c|}{ Phase I } & \multicolumn{3}{|c|}{ Phase II } & \multicolumn{3}{|c|}{ Phases I and II } & & & & \multicolumn{2}{|c|}{ Layer Ia } & \multicolumn{2}{|c|}{ Layer Ib } \\
\hline & NISP & MNI & $\mathrm{mW}(\mathrm{kg})$ & NISP & $\mathrm{MNI}$ & $\mathrm{mW}(\mathrm{kg})$ & NISP & MNI & mW (kg) & NISP & MNI & $\mathrm{mW}(\mathrm{kg})$ & NISP & MNI & NISP & $\mathrm{MNI}$ \\
\hline Bos primigenius & 2 & 1 & 128 & 16 & 2 & 2329 & - & - & - & 3 & 1 & 137 & 5 & 2 & 7 & 1 \\
\hline Bos taurus & 156 & 10 & 3979 & 627 & 13 & 17,629 & 43 & 3 & 2015 & 15 & 3 & 128 & 235 & 12 & 200 & 14 \\
\hline Bos sp. & - & - & - & - & - & - & - & - & - & 4 & 1 & 132 & - & - & - & - \\
\hline Ovis aries & 5 & 2 & 70 & 40 & 4 & 361 & 2 & 2 & 20 & 5 & 2 & 16 & - & - & - & - \\
\hline Capra hircus & 1 & 1 & 4 & - & - & - & - & - & - & 1 & 1 & 70 & 55 & 5 & 123 & 11 \\
\hline Ovis/Capra & 100 & 8 & 495 & 374 & 17 & 1815 & 22 & 2 & 115 & 74 & 7 & 157 & 1967 & 68 & 4196 & 120 \\
\hline Sus ferus & - & - & - & 9 & 3 & 316 & - & - & - & - & - & - & 46 & 7 & 108 & 13 \\
\hline Sus domesticus & 1 & 2 & 11 & 29 & 3 & 349 & 1 & 1 & 10 & - & - & - & 504 & 37 & 713 & 41 \\
\hline Sus sp. & 2 & 2 & 5 & 7 & 1 & 51 & - & - & - & 11 & 5 & 27 & - & - & - & - \\
\hline Cervus elaphus & 2 & 1 & $*$ & 3 & 1 & 67 & 7 & 2 & 26 & 2 & 1 & 24 & 393 & 14 & 664 & 13 \\
\hline Capreolus capreolus & - & - & - & 1 & 1 & $*$ & 1 & 1 & $*$ & - & - & - & 20 & 3 & 58 & 6 \\
\hline Equus caballus & - & - & - & 1 & 1 & 99 & 1 & 1 & 8 & 1 & 1 & 107 & 5 & 1 & 7 & 2 \\
\hline Total & 269 & 26 & 4692 & 1107 & 46 & 23,016 & 77 & 12 & 2194 & 116 & 22 & 798 & 3230 & 149 & 6076 & 221 \\
\hline
\end{tabular}

*Meat weight was not calculated since the available remains consisted of antler fragments

standing. If this were the case, we might expect some concomitant differences in mortuary treatment or age/sex-related divergences, like those detected in other Neolithic sites such as Can Gambús in Catalonia, where the results show a significant enrichment in both $\delta^{13} \mathrm{C}$ and $\delta^{15} \mathrm{~N}$ among men, especially older individuals, who not only were buried in monumental funerary structures but also were associated with qualitatively and quantitatively superior grave goods (Fontanals-Coll et al. 2015). However, these are not observed in our sample: all are pit graves, no associations between the presence/absence of grave goods and the isotopic data are found (cf. Table A.2) and, while some age-related differences are present (cf. Table A.4), they do not account for the observed correlation. Thus, while not excluding the possibility of the existence of status-related dietary distinctions, the lack of archaeological correlates does undermine this interpretation, at least pending further investigation.

On the other hand, it may be that some specialization in subsistence activities - such as livestock herding and crop farming - existed. For example, in the Languedoc region of southern France, those interred in stone cists and those deposited in pit graves show statistically distinct isotopic values, interpreted as reflecting differing emphases on herding and arable farming, respectively (Le Bras-Goude et al. 2013). No such a link between funerary and isotopic variability has been found here. Of course, this need not imply the absence of some degree of economic differentiation. Indeed, the existence of economic specializations among the first Neolithic groups has been proposed for the middle Ebro valley. Here, seasonal transhumant herders could have moved cyclically to the mountains with their livestock, while the rest of the community would remain in valley settlements (e.g. Rojo-Guerra et al. 2013: 45). Other studies, conversely, suggest that most of the Neolithic sites in north-eastern Iberia, including those in upland areas, would have been settled by more or less permanent mixed farming communities, where herding was probably limited to short-distance movements (Antolín et al. 2018). Although in this model the existence of such an economic specialization would be not so obvious, it still may exist. In any case, it is clear that, whether for questions relating to social differentiation or to economic specialization, not all the people interred at Los Cascajos and Paternanbidea consumed the same amounts and/or quality of animal protein.

A further question arises as to whether the origins of the positive correlation between human $\delta^{13} \mathrm{C}$ and $\delta^{15} \mathrm{~N}$ values at Los Cascajos and Paternanbidea are diachronic. The available radiocarbon dates provide no suggestion of any temporal trends at the currently available resolution, given the modest number of determinations (cf. Fig. 2). But this does not exhaust the possibilities, as only persistent directional shifts in subsistence practices would be discernible isotopically at this resolution. Short-term oscillations on the order of decades could be sufficient to result in isotopic differences in adult bone collagen, but insufficient to be detected in the radiocarbon chronology, even with Bayesian modelling, unless data were available for many more individuals, if then. Underlying such a scenario would be a shifting emphasis on the consumption of cereals versus animal foods, particularly young animals 


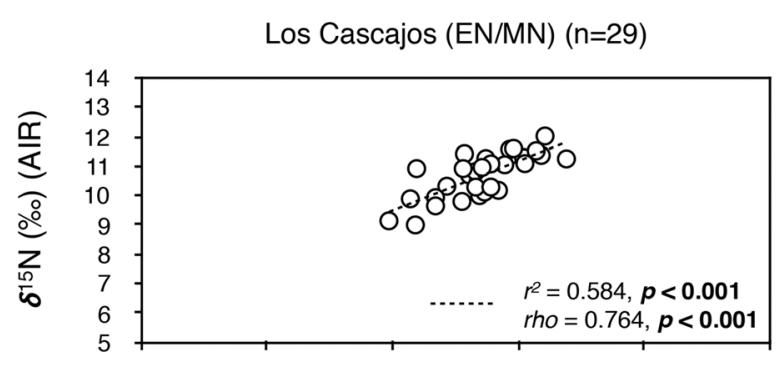

Puig d'en Roca (MN) $(n=5)$

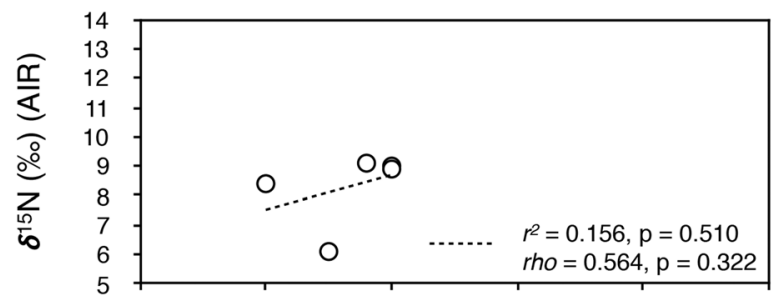

Can-Gambús (MN) $(\mathrm{n}=37)^{\star}$

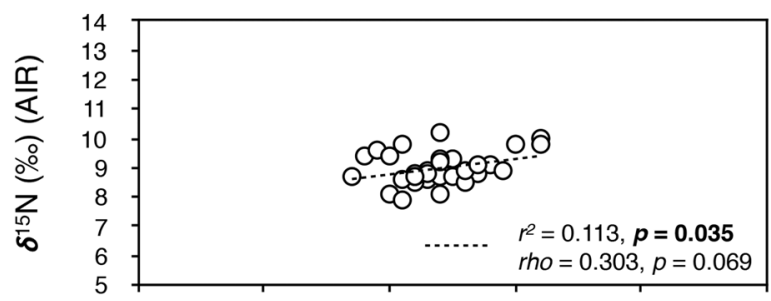

Tossal de les Basses $(\mathrm{MN})(\mathrm{n}=11)$

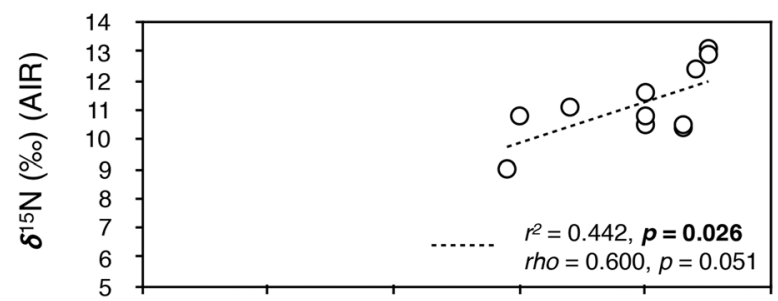

Cadaval $(M N)(n=7)$

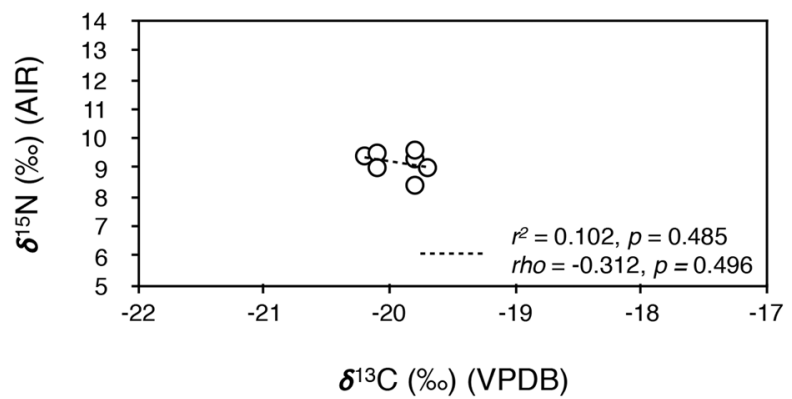

Fig. 7 Correlations between $\delta^{13} \mathrm{C}$ and $\delta^{15} \mathrm{~N}$ human values at Los Cascajos and Paternanbidea, compared with those from other Early and Middle Neolithic Iberian sites (Puig d'en Roca (Gibaja et al. 2017); La Bòbila Madurell and Can Gambús (Fontanals-Coll et al. 2015); Can Roqueta-Can Revella (Fontanals-Coll et al. 2017); Tossal de les Basses (Salazar-García et al. 2016); Castelo Belinho (Carvalho and Petchey 2013); Cadaval (Guiry et al. 2016)). Iberian sites with less than five
Paternanbidea $(E N)(n=10)$

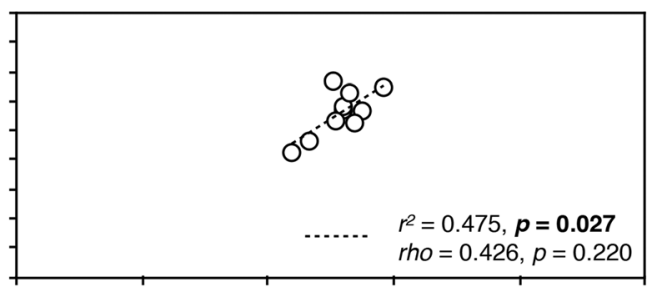

La Bòbila-Madurell (MN) $(n=54)$

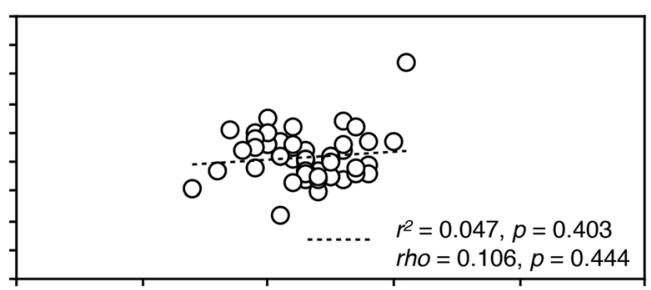

Can Roqueta - Can Revella (MN) $(n=6)$

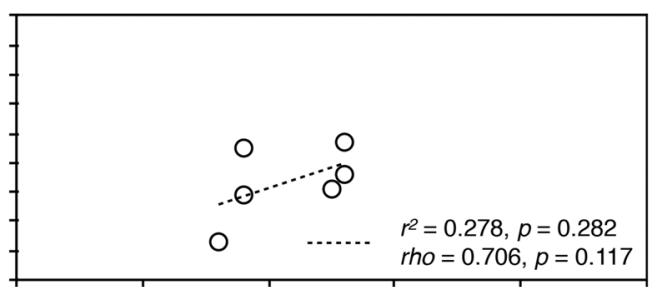

Castelo Belinho (EN/MN) $(n=9)$

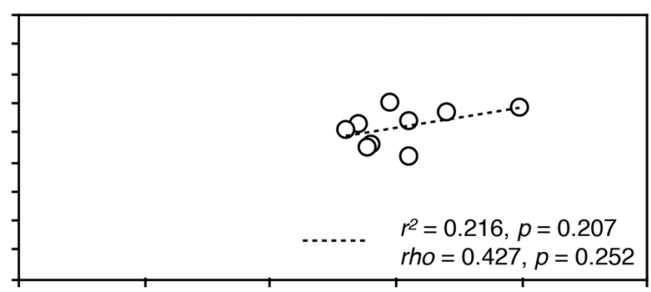

SITES GROUPED (EN/MN) $(n=168)$

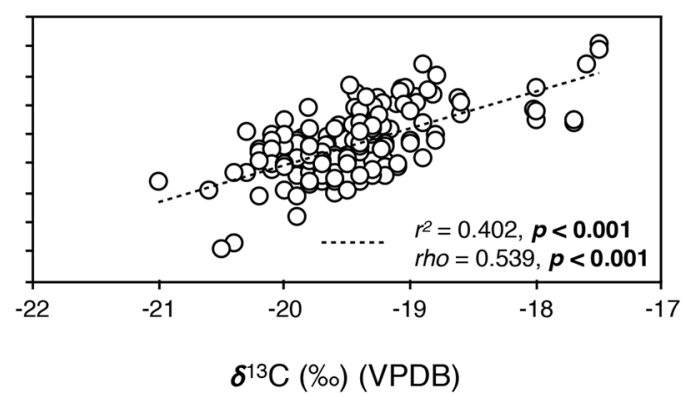

human samples with acceptable values have not been included in the comparison. Single asterisk indicates that one individual has been excluded from the correlation model in the case of Can-Gambús, for being a clear outlier in $\delta^{13} \mathrm{C}(-16.8 \%$ o $)$ compared with the rest of the samples (Fontanals-Coll et al. 2015); in any case, its inclusion only increases the strength of the correlation 
Fig. 8 Comparison between Early/Middle Neolithic and Late Neolithic/Early Chalcolithic $\delta^{13} \mathrm{C}$ and $\delta^{15} \mathrm{~N}$ human values of the Ebro Valley (Fernández-Crespo and Schulting 2017; VillalbaMouco et al. 2018b; this paper)
MID-UPPER EBRO VALLEY

O Early/Middle Neolithic (this paper) $(n=44)$

$\Delta$ Late Neolithic/Early Chalcolithic (Fernández-Crespo and Schulting 2017) $(n=116)$

$\square$ Late Neolithic and Chalcolithic (Villalba-Mouco et al. 2018b) $(n=40)$

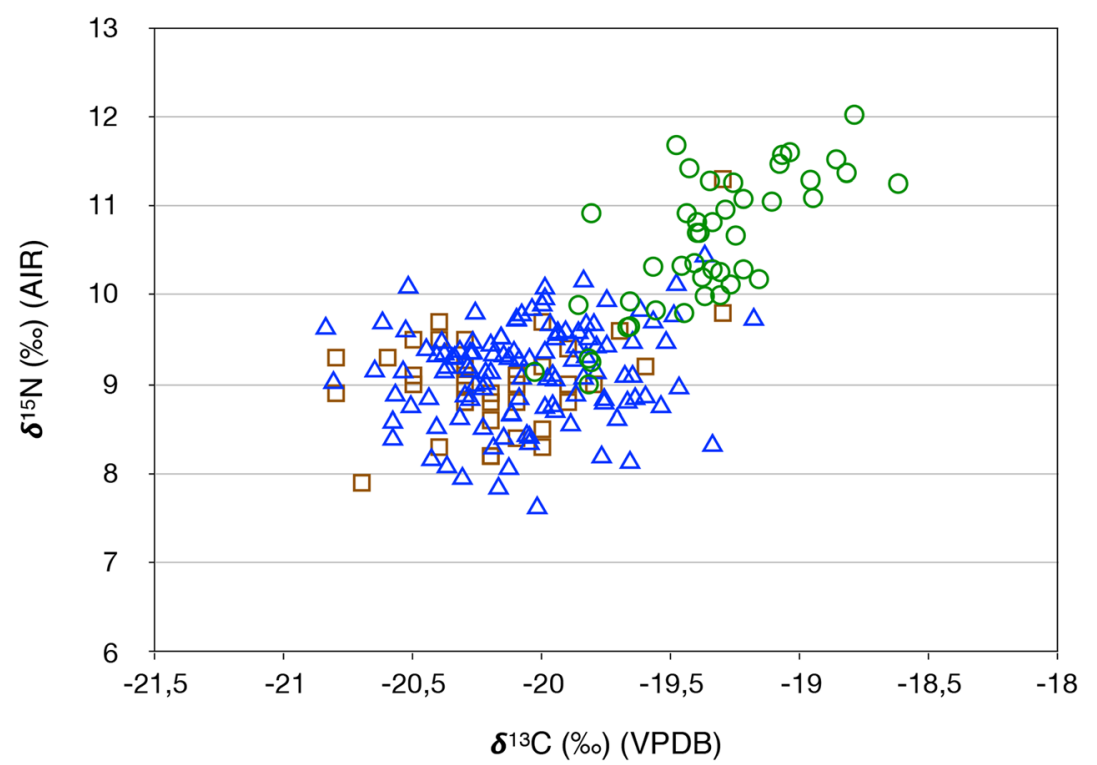

retaining elements of a nursing signal. Such shifts would need to persist for a decade or so in order to be visible isotopically, and could be the result of a combination of a series of failed crops (e.g. a number of poor rainfall years, or domestic stock falling prey to disease or to human predation). This would be far from unexpected in an agro-pastoral economy, the question then becoming why such a pattern has not been detected more widely across Europe, where similar considerations would presumably apply. This would bear revisiting, but the current impression is that this pattern is not repeated with anything approaching the consistency seen in the present study area.

\section{Shift in human isotope values between the Early- Middle and the Late Neolithic/Early Chalcolithic}

Widening the comparison, the Early-Middle Neolithic human isotope values discussed in this paper differ substantially from those of the Late Neolithic/Early Chalcolithic in the same region, which show notably lower carbon and, especially, nitrogen isotope values (Fig. 8), a far weaker positive correlation between $\delta^{13} \mathrm{C}$ and $\delta^{15} \mathrm{~N}$ and smaller human-herbivore offsets in those sites with enough faunal data (e.g. Los Husos I: $0.5 \%$ o for $\delta^{13} \mathrm{C}$ and $4.2 \%$ or for $\delta^{15} \mathrm{~N}$; Abauntz: $1.2 \%$ for $\delta^{13} \mathrm{C}$ and $4.8 \%$ for $\delta^{15} \mathrm{~N}$ ) (Fernández-Crespo and Schulting 2017; Villalba-Mouco et al. 2018b). This shift in subsistence, described here for the first time, may tentatively be related to the stronger emphasis on pastoralism increasingly being attributed to the earliest Neolithic communities of interior Iberia (e.g. Carvalho 2015; Guerra-Doce et al. 2017), which is consistent with the local palynological (e.g. López-García and López-Sáez 2000; Pérez-Díaz et al. 2015) and zooarchaeological records (Castaños 2004). Similar subsistence models characterized by a high reliance on animal resources have been proposed in other western European regions, including Britain, where $\delta^{15} \mathrm{~N}$ values are also relatively high compared with Central Europe (Schulting and Borić 2017). Unfortunately, it remains unknown whether this potentially greater commitment to a herding economy attributed to the first north-central Iberian Neolithic groups would involve a significant degree of mobility (transhumance, transterminance) or not (e.g. 'from dawn till dusk'). In any case, it is possible that, rather than a fully arable economy, Early and Middle Neolithic subsistence practices in the region emphasized intensive dairying and domestic herbivore meat exploitation complemented by the hunting of ungulates (Altuna 1980; Castaños 1997; Castaños 2004), gathering of wild plants and a small-scale intensive and diversified agriculture based on the cultivation of small cereal plots (Zapata et al. 2004; Zapata et al. 2008). This model could be the precursor to more extensive cereal-based farming from the Late Neolithic onwards, as both the isotope evidence (FernándezCrespo and Schulting 2017; Villalba-Mouco et al. 2018b) and the environmental and archaeological records suggest (Fernández-Eraso et al. 2015; Pérez-Díaz et al. 2015).

\section{Conclusion}

The human and faunal isotopic results from the Early-Middle Neolithic pit-grave cemeteries of interior north-central Iberia 
analyzed are consistent with an isotopically similar $\mathrm{C}_{3}$ plantand terrestrial animal-based diet. However, the spacing between the humans and herbivores is higher than expected for both isotopes. This is observable here and in other large coeval Iberian sites and suggests that an important food source may not be accurately represented in the isotope studies and in the archaeological record. Although it is unclear at present what this might be, we propose a high consumption of non-adult domestic herbivores as the most likely hypothesis, at least for the study region. In addition, a positive correlation observed between carbon and nitrogen isotopic values in Los Cascajos and Paternanbidea, also detected in other coeval Iberian sites, is seen. This may indicate consumption of different foods within the community, with relevant implications for the understanding of the subsistence strategies (e.g. economic specialization) and/or social practices (e.g. differential diets based on status) followed by Iberian early farming societies. Finally, the results also show a significant shift in diet between the Early/Middle Neolithic and the Late Neolithic in northcentral Iberia, which possibly relates to a subsistence change from mainly pastoral to mixed economies.

Acknowledgements We are grateful to Rowena Henderson for helping with sample preparation, Peter Ditchfield for mass spectrometry technical support, and to Julia Lee-Thorp and Iñigo García-Martínez de Lagrán for their useful suggestions.

Funding information This research was funded by the Basque Government (POS_2013_1_147; POS_2014_2_24; POS_2015_2 0001) and the Spanish Ministry of Economy and Competitiveness (project 'Coastal societies in a changing world: A diachronic and comparative approach to the Prehistory of SW Europe from the late Palaeolithic to the Neolithic (CoChange)' (HAR2014-51830-P)). The study has also been supported by a Newton International Fellowship funded by the British Academy (NF170854); the Basque Government (IT542/10); the University of the Basque Country (UPV/EHU) (UFI11/09); and the Spanish Ministry of Science and Innovation (projects 'Los Caminos del Neolítico' (HAR2009-09027) and 'Los Caminos del Neolítico II' (HAR2013-46800-P)).

Open Access This article is distributed under the terms of the Creative Commons Attribution 4.0 International License (http:// creativecommons.org/licenses/by/4.0/), which permits unrestricted use, distribution, and reproduction in any medium, provided you give appropriate credit to the original author(s) and the source, provide a link to the Creative Commons license, and indicate if changes were made.

\section{References}

Alameda MC, Carmona E, Pascual S, Martínez G, Díez C (2011) El "campo de hoyos" calcolítico de Fuente Celada (Burgos): datos preliminares y perspectivas. Complutum 22(1):47-69

Alday A (2005) The transition between the last hunter-gatherers and the first farmers in south-western Europe. J Anthropol Res 61:469-494

Alday A (2012) The Neolithic in the Iberian Peninsula. An explanation from the perspective of the participation of Mesolithic communities. Zephyrus LXIX:75-94
Alonso C, Jiménez J (2014) Contribución al estudio del poblamiento, modos de vida y ritual funerario del Neolítico Antiguo: el asentamiento al aire libre de El Prado (Pancorbo, Burgos). Zephyrus LXXIV:41-64

Alonso C, Jiménez J (2015) El neolítico en el corredor Alto Ebro-Alto Duero: dos hallazgos funerarios del Neolítico Antiguo y Reciente en Monasterio de Rodilla (Burgos). In: Gonçalves VS, Diniz M, Sousa AC (eds) $5^{\circ}$ Congresso do Neolítico Peninsular. Actas. UNIARQ, Lisboa, pp 540-546

Altuna J (1980) Historia de la domesticación animal en el País Vasco desde sus orígenes hasta la romanización. Munibe (AntropologiaArkeologia) 32:1-164

Altuna J, Mariezkurrena K (2001) La cabaña ganadera del yacimiento de La Renke. Munibe (Antropologia-Arkeologia) 53:75-86

Altuna J, Mariezkurrena K (2009) Tipos de cabañas ganaderas durante el Neolítico en el País Vasco y zonas próximas. Archaeofauna 18:137-157

Altuna J, Mariezkurrena K (2019) La cabaña ganadera de los pobladores del yacimiento de Los Cascajos (Los Arcos, Navarra). In: RojoGuerra MA, Sesma-Sesma J, García-Gazólaz J (eds) Memoria de las excavaciones arqueológicas en el poblado neolítico de Los Cascajos (Los Arcos, Navarra). Trabajos de Arqueología Navarra. Institución Príncipe de Viana, Gobierno Foral de Navarra, Pamplona

Ambrose SH (1990) Preparation and characterization of bone and tooth collagen for isotopic analysis. J Archaeol Sci 17:431-451

Antolín F, Navarrete V, Saña M, Viñerta A, Gassiot E (2018) Herders in the mountains and farmers in the plains? A comparative evaluation of the archaeological record from Neolithic sites in the eastern Iberian Pyrenees and the southern lower lands. Quat Int 484:75-83

Beaumont J, Montgomery J (2016) The great Irish famine: identifying starvation in the tissues of victims using stable isotope analysis of bone and incremental dentine collagen. PLoS One 11(8):e0160065

Bernabeu J, Barton CM, Pardo S, Bergin SM (2015) Modeling initial Neolithic dispersal. The first agricultural groups in West Mediterranean. Ecol Model 307:22-31

Brock F, Higham TFG, Ditchfield P, Bronk Ramsey C (2010) Current pretreatment methods for AMS radiocarbon dating at the Oxford Radiocarbon Accelerator Unit (ORAU). Radiocarbon 52(1):102-112

Bronk Ramsey C (2009) Bayesian analysis of radiocarbon dates. Radiocarbon 51:337-360

Brooks ST, Suchey JM (1990) Skeletal age determination based on the os pubis: a comparison of Acsádi-Nemeskéri and Suchey-Brooks methods. Hum Evol 5:227-238

Brothwell DR (1989) The relationship of tooth wear to aging. In: Iscan MY (ed) Age markers in the human skeleton. Charles C. Thomas, Springfield, pp 303-316

Buikstra JE, Ubelaker DH (1994) Standards for data collection from human skeletal remains. In: Haas J (ed) Proceedings of a seminar at the Field Museum of Natural History. Arkansas Archaeological Survey Research Series 44. Arkansas Archaeological Survey Press, Fayetteville

Carvalho AF (2015) A two-stage economic succession at the inception of farming in central Portugal. Preliminary examination of possible causes and consequences. Vegueta 15:89-109

Carvalho AF, Petchey F (2013) Stable isotope evidence of Neolithic palaeodiets in the coastal regions of southern Portugal. J Isl Coast Archaeol 8(3):361-383

Castaños PM (1997) Estudio zooarqueológico de la fauna de Peña Larga (Cripán, Álava). In: Fernández-Eraso J (ed) Peña Larga, Memorias de Yacimientos Alaveses, vol 4. Diputación Foral de Álava, VitoriaGasteiz, pp 127-134

Castaños PM (2004) Estudio arqueozoológico de los macromamíferos del Neolítico de la cueva de Chaves (Huesca). Salduie 4:125-172

Castaños PM (2005) El estudio arqueozoológico de la fauna de Mendandia (Sáseta, Treviño). In: Alday A (ed) El campamento prehistórico de Mendandia: ocupaciones mesolíticas y neolíticas 
entre el 8.500 y el 6.400 BP, Colección Barandiarán, vol 9. Diputación Foral de Álava, Vitoria-Gasteiz, pp 427-448

Coplen TB, Brand WA, Gehre M, Gröning M, Meijer HJ, Toman B, Verkouteren RM (2006) New guidelines for $\delta^{13} \mathrm{C}$ measurements. Anal Chem 78:2439-2441

Cubas M, Altuna J, Álvarez-Fernández E, Armendariz A, Fano MA, López-Dóriga IL, Mariezkurrena K, Tapia J, Teira LC, Arias P (2016) Re-evaluating the Neolithic: the impact and the consolidation of farming practices in the Cantabrian region (northern Spain). J World Prehist 29(1):79-116

DeNiro MJ (1985) Post-mortem preservation and alteration of in vivo bone collagen isotope ratios in relation to palaeodietary reconstruction. Nature 317:806-809

DeNiro MJ, Epstein S (1978) Influence of diet on the distribution of carbon isotopes in animals. Geochim Cosmochim Acta 42:495-506

DeWitte SN, Stojanowski CM (2015) The osteological paradox 20 years later: past perspectives, future directions. J Archaeol Res 23:397450

Dufour E, Bocherens H, Mariotti A (1999) Palaeodietary implications of isotopic variability in Eurasian lacustrine fish. J Archaeol Sci 26: 617-627

Ferembach D, Schwidetzky I, Stloukal M (1980) Recommendations for age and sex diagnosis of skeletons. J Hum Evol 9:517-549

Fernandes R, Millard AM, Brabec M, Nadeau MJ, Grootes P (2014) Food reconstruction using isotopic transferred signals (FRUITS): a Bayesian model for diet reconstruction. PLoS One 9(2):e87436

Fernández-Crespo T, Schulting R (2017) Living different lives: early social differentiation identified through linking mortuary and isotopic variability in Late Neolithic/Early Chalcolithic north-central Spain. PLoS One 12(9):e0177881. https://doi.org/10.1371/journal. pone. 0177881

Fernández-Crespo T, Schulting R, Arias P (2019) Cronología radiocarbónica y análisis de isótopos estables de carbono y nitrógeno en el yacimiento neolítico de Los Cascajos (Los Arcos, Navarra). In: Rojo-Guerra MA, Sesma-Sesma J, García-Gazólaz J (eds) Memoria de las excavaciones arqueológicas en el poblado neolítico de Los Cascajos (Los Arcos, Navarra). Trabajos de Arqueología Navarra. Institución Príncipe de Viana, Gobierno Foral de Navarra, Pamplona

Fernández-Eraso J, Mujika J, Zapata L, Iriarte MJ, Polo-Díaz A, Castaños P, Tarriño A, Cardoso S, Sesma-Sesma J, García-Gazólaz J (2015) Beginnings, settlement and consolidation of the production economy in the Basque region. Quat Int 364:162-171

Fontanals-Coll M, Subirá ME, Díaz-Zorita M, Duboscq S, Gibaja JF (2015) Investigating palaeodietary and social differences between two differentiated sectors of a Neolithic community, La Bòbila Madurell-Can Gambús (north-east Iberian Peninsula). J Archaeol Sci Rep 3:160-170

Fontanals-Coll M, Subirá ME, Díaz-Zorita M, Gibaja JF (2017) First insight into the Neolithic subsistence economy in the north-east Iberian Peninsula: paleodietary reconstruction through stable isotopes. Am J Phys Anthropol 162(1):36-50

Gamba C, Fernández E, Tirado M, Deguilloux MF, Pemonge MH, Utrilla P, Edo M, Molist M, Rasteiro R, Chikhi L, Arroyo-Pardo E (2012) Ancient DNA from an Early Neolithic Iberian population supports a pioneer colonization by first farmers. Mol Ecol 21:45-56

García-Gazólaz J (2007) Los enterramientos neolíticos del yacimiento de Paternanbidea (Ibero). In: La tierra te sea leve, Arqueología de la muerte en Navarra. Museo de Navarra, Pamplona, pp 59-65

García-Gazólaz J, Sesma-Sesma J (2001) Los Cascajos (Los Arcos, Navarra). Intervenciones 1996-1999. Trab Arqueol Navar 15:299306

García-Gazólaz J, Sesma-Sesma J (2007) Los enterramientos en el poblado Neolitico de Los Cascajos (Los Arcos). In: La tierra te sea leve, Arqueología de la muerte en Navarra. Museo de Navarra, Pamplona, pp 49-58
García-Martínez de Lagrán I (2012) El proceso de neolitización en el interior peninsular: la Submeseta Norte y el Alto Valle del Ebro. El análisis de la cerámica como herramienta interpretativa. $\mathrm{PhD}$ thesis, Universidad de Valladolid

García-Martínez de Lagrán I (2015) Recent data and approaches on the neolithization of the Iberian Peninsula. Eur J Archaeol 18(3):429-453

García-Martínez de Lagrán I (2018) Review of the archaeological contexts and theoretical models of the Neolithisation of Spain: the North Meseta, the Ebro Valley and Catalonia as a case study. Quat Int 472(B):172-194. https://doi.org/10.1016/j.quaint.2016.12.043

Gibaja JF, Fontanals-Coll M, Dubosq S, Oms FX, Augé A, Santos FJ, Morell B, Subirá ME (2017) Human diet and the chronology of Neolithic societies in the north-east of the Iberian Peninsula: the necropolises of Puig d'en Roca and Can Gelats (Girona, Spain). Archaeol Anthropol Sci 9(5):903-913

Gillis R, Carrère I, Saña M, Radi G, Vigne JD (2014) Neonatal mortality, young calf slaughter and milk production during the Early Neolithic of north western Mediterranean. Int J Osteoarchaeol 26(2):303-313

Goude G, Fontugne M (2016) Carbon and nitrogen isotopic variability in bone collagen during the Neolithic period: influence of environmental factors and diet. J Archaeol Sci 70:117-131

Guerra-Doce E, Zapatero P, Cruz PJ, López-Sáez JA, Abel D, Fabián JF, Alonso-Gavilán G, Riquelme JA (2017) Datos sobre la neolitización del valle de Amblés a la luz de la excavación del yacimiento de La Atalaya (Muñopepe, Ávila). BSAA Arqueología LXXXIII:11-70

Guiry EJ, Hillier M, Boaventura R, Silva AM, Oosterbeek L, Tomé T, Valera A, Cardoso JL, Hepburn JC, Richards MP (2016) The transition to agriculture in south-western Europe: new isotopic insights from Portugal's Atlantic coast. Antiquity 90:606-616

Harbeck M, Grupe G (2009) Experimental chemical degradation compared to natural diagenetic alteration of collagen: implications for collagen quality indicators for stable isotope analysis. Archaeol Anthropol Sci 1:43-57

Hedges REM, Reynard LM (2007) Nitrogen isotopes and the trophic level of humans in archaeology. J Archaeol Sci 34(8):1240-1251

Hedges REM, Saville A, O'Connell TC (2008) Characterizing the diet of individuals at the Neolithic chambered tomb of Hazleton North, Gloucestershire, England, using stable isotope analysis. Archaeometry 50(1):114-128

Hedges REM, Bentley RA, Bickle P, Cullen P, Dale C, Fibiger L, Hamilton J, Hofmann D, Nowell G, Whittle A (2013) The supraregional perspective. In: Bickle P, Whittle A (eds) The first farmers of central Europe. Diversity in LBK lifeways. Oxbow, Oxford, pp 341-385

Hervella M, Izagirre N, Alonso S, Fregel R, de-la-Rúa C (2014) Early Neolithic funerary diversity and mitochondrial variability of two Iberian sites. Archaeol Anthropol Sci 8(1):97-106

Hollund HI, Higham T, Belinskij A, Korenevskij S (2010) Investigation of palaeodiet in the North Caucasus (South Russia) Bronze Age using stable isotope analysis and AMS dating of human and animal bones. J Archaeol Sci 37:2971-2983

Hull B (2008) Diet and social differentiation in Early Anglo-Saxon England: stable isotope analysis of archaeological human and faunal remains. $\mathrm{PhD}$ thesis. University of Oxford

Iriarte MJ (2009) Vegetation landscape and the anthropization of the environment in the central sector of the northern Iberian Peninsula: current status. Quat Int 200:66-76

Isern N, Zilhão J, Fort J, Ammerman AJ (2017) Modeling the role of voyaging in the coastal spread of the Early Neolithic in the West Mediterranean. PNAS 114(5):897-902

van Klinken GJ (1999) Bone collagen quality indicators for palaeodietary and radiocarbon measurements. J Archaeol Sci 26(6):687-695

Lazaridis I, Nadel D, Rollefson G, Merrett DC, Rohland N, Mallick S, Fernandes D, Novak M, Gamarra B, Sirak K, Connell S, Stewardson K, Harney E, Fu Q, Gonzalez-Fortes G, Jones ER, AlpaslanRoodenberg S, Lengyel GR, Bocquentin F, Gasparian B, Monge 
JM, Gregg M, Eshed V, Mizrahi AS, Meiklejohn C, Gerritsen F, Bejenaru L, Blüher M, Campbell A, Cavalleri G, Comas D, Froguel P, Gilbert E, Kerr SM, Kovacs P, Krause J, McGettigan D, Merrigan M, Merriwether DA, O'Reilly S, Richards MB, Semino O, Shamoon-Pour M, Stefanescu G, Stumvoll M, Tönjes A, Torroni A, Wilson JF, Yengo L, Hovhannisyan NA, Patterson N, Pinhasi R, Reich D (2016) Genomic insights into the origin of farming in the ancient Near East. Nature 536:419-424

Le Bras-Goude G, Herrscher E, Vaquer J (2013) Funeral practices and foodstuff behaviour: what does eat meat mean? Stable isotope analysis of Middle Neolithic populations in the Languedoc region (France). J Anthropol Archaeol 32(3):280-287

Longin R (1971) New method of collagen extraction for radiocarbon dating. Nature 230:241-242

López-García P, López-Sáez JA (2000) Le paysage et la phase épipaléolithique-mésolithique dans les Pre-Pyrénées aragonaises et le bassin moyen de l'Ebre à partir de l'analyse palynologique. In: Les derniers chasseurs cueilleurs d'Europe occidentale (13.0005.5000 av J.C.). Annales Littéraires 699:59-69

Lovejoy CO, Meindl RS, Pryzbeck TR, Mensforth RP (1985) Chronological metamorphosis of the auricular surface of the ilium. A new method for the determination of adult skeletal age at death. Am J Phys Anthropol 68(1):15-28

Montero S, Liesau C (2008) La fauna recuperada en las áreas de hábitat de La Lámpara y de La Revilla. In: Rojo-Guerra MA, Kunst M, Garrido-Pena R, García-Martínez de Lagrán I, Morán G (eds) Paisajes de la memoria: asentamientos del Neolítico Antiguo en el Valle de Ambrona. Universidad de Valladolid, Valladolid, pp 535570

Moreno-Larrazabal A, Teira-Brión A, Sopelana-Salcedo I, ArranzOtaegui A, Zapata L (2015) Ethnobotany of millet cultivation in the north of the Iberian Peninsula. Veg Hist Archaeobotany 24: $541-554$

Ninyerola M, Pons X, Roure JM (eds) (2005) Atlas Climático Digital de la Península Ibérica. Metodología y aplicaciones en bioclimatología y geobotánica. Universidad Autónoma de Barcelona, Bellaterra

O'Connell T, Kneale CJ, Tasevska N, Kuhnle GGC (2012) The diet-body offset in human nitrogen isotopic values: a controlled dietary study. Am J Phys Anthropol 149(3):426-434

Olalde I, Schroeder H, Sandoval-Velasco M, Vinner L, Lobón I, Ramirez O, Civit S, García Borja P, Salazar-García DC, Talamo S, Fullola JM, Oms FX, Pedro M, Martínez P, Sanz M, Daura J, Zilhão J, Marquès-Bonet T, Gilbert MTP, Lalueza-Fox C (2015) A common genetic origin for early farmers from Mediterranean cardial and central European LBK cultures. Mol Biol Evol 32(12):3132-3142

Palomino AL, Rojo-Guerra MA, García-Martínez de Lagrán I, GarridoPena R, Alday A, García-Gazólaz J, Sesma-Sesma J (2011) El Molino de Arriba (Buniel, Burgos). In: Bernabéu J, Rojo-Guerra MA, Molina L (eds) Las primeras producciones cerámicas: el VI milenio cal. AC en la Península Ibérica, Sagvntvm Extra, vol 12. Universidad de Valencia, Valencia, pp 113-116

Peña-Chocarro L, Zapata L, Iriarte MJ, González Morales MR, Straus LG (2005) The oldest agriculture in northern Atlantic Spain: new evidence from El Mirón cave (Ramales de la Victoria, Cantabria). J Archaeol Sci 32(4):579-587

Peña-Chocarro L, Pérez-Jordà G, Morales J, Zapata L (2013) Neolithic plant use in the western Mediterranean region: preliminary results from the AGRIWESTMED project. Ann Bot 3:135-141

Pérez-Díaz S, López-Sáez JA, Galop D (2015) Vegetation dynamics and human activity in the Western Pyrenean Region during the Holocene. Quat Int 364:65-77

Polo A, Fernández-Eraso J (2008) Aportación de la micromorfología a la determinación de los rediles prehistóricos en el alto valle del Ebro: el caso del Neolítico de Los Husos II (Elvillar, Álava). Rev C \& G 22(3-4):159-171
Raemaekers DCM (2014) The persistence of hunting and gathering amongst farmers in Prehistory in Neolithic north-west Europe. In: Cummings V, Jordan P, Zvelebil M (eds) The Oxford Handbook of the Archeology and Anthropology of Hunter-Gatherers. Oxford University Press, Oxford, pp 805-823

Reimer PJ, Bard E, Bayliss A, Beck JW, Blackwell PG, Bronk Ramsey C, Buck CE, Cheng H, Edwards RL, Friedrich M, Grootes PM, Guilderson TP, Haflidason H, Hajdas I, Hatté C, Heaton TJ, Hoffmann DL, Hogg AG, Hughen KA, Kaiser KF, Kromer B, Manning SW, Niu M, Reimer RW, Richards DA, Scott EM, Southon JR, Staff RA, Turney CSM, van der Plicht J (2013) IntCal13 and Marine13 radiocarbon age calibration curves 0-50, 000 years cal BP. Radiocarbon 55(4):1869-1887

Richards MP, Hedges REM (1999) Stable isotope evidence for similarities in the types of marine foods used by Late Mesolithic humans at sites along the Atlantic coast of Europe. J Archaeol Sci 26:717-722

Richards MP, Schulting RJ, Hedges REM (2003) Sharp shift in diet at onset of Neolithic. Nature 425:366

Rofes J, Zuluaga MC, Murelaga X, Fernández-Eraso J, Bailon S, Iriarte MJ, Ortega LA, Alonso-Olazabal A (2013) Paleoenvironmental reconstruction of the early Neolithic to middle Bronze Age Peña Larga rock shelter (Álava, Spain) from the small mammal record. Quat Res 79:158-167

Rojo-Guerra MA, Kunst M (1999) La Lámpara y La Peña de la Abuela. Propuesta secuencial del Neolítico Interior del ámbito funerario. In: Bernabeu J, Orozco T (eds) II Congrés del Neolític a la Península Ibèrica, Sagvntvm-Plav Extra-2. Universidad de Valencia, Valencia, pp 503-512

Rojo-Guerra MA, Kunst M, Garrido-Pena R, García-Martínez de Lagrán I, Morán G (eds) (2008) Paisajes de la memoria: asentamientos del Neolítico Antiguo en el Valle de Ambrona. Universidad de Valladolid, Valladolid

Rojo-Guerra MA, Peña-Chocarro L, Royo JI, Tejedor C, García-Martínez de Lagrán I, Arcusa H, Garrido-Pena R, Moreno-García M, Mazzuco N, Gibaja JF, Ortega D, Kromer B, Alt KW (2013) Pastores trashumantes del Neolítico Antiguo en un entorno de alta montaña: secuencia crono-cultural de la Cova de Els Trocs (San Feliú de Veri, Huesca). BSAA Arqueología LXXIX:9-55

Rojo-Guerra MA, García-Martínez de Lagrán I, Garrido-Pena R, Tejedor C, Subirá E, García-Gazólaz J, Sesma-Sesma J, Gibaja JF, Unzu M, Palomino AL, Jiménez I, Arroyo E, Arcusa H (2016) Enterramientos del Neolítico antiguo en el interior peninsular: nuevos datos para una actualización de la evidencia empírica. In: Bonet H (ed) Del neolític a l'edat del bronze en el Mediterrani occidental. Estudis en homenatge a Bernat Martí Oliver, Trabajos Varios, vol 119. Diputación de Valencia, Valencia, pp 181-210

Salazar-García DC (2009) Estudio de la dieta en la población Neolítica de Costamar. Resultados preliminares de análisis de isótopos estables de carbono y nitrógeno. In: Flors E (ed) Torre de la Sal (Ribera de Cabanes, Castellón). Evolución del paisaje antrópico desde la Prehistoria hasta el medioevo, Monografies de Prehistoria i Arqueologia Castellonenses, vol 8. Diputación de Castellón, Castellón, pp 411-418

Salazar-García DC (2010) Estudio de la dieta en poblaciones mesolíticas y neolíticas del sur del País Valenciano. Resultados preliminares de análisis de isótopos estables del C y del N. In: Gutiérrez-Redomero E, Sánches A, Galera V (eds) Diversidad humana y antropología aplicada. Universidad de Alcalá, Madrid, pp 145-155

Salazar-García DC, Romero A, García-Borja P, Subirá ME, Richards MP (2016) A combined dietary approach using isotope and dental buccal-microwear analysis of human remains from the Neolithic, Roman and Medieval periods from the archaeological site of Tossal de les Basses (Alicante, Spain). J Archeol Sci: Rep 6:610 619

Saña M (2000) La gestió i explotació dels recursos animals. In: Bosch A, Chinchilla J, Tarrús J (eds) El poblat lacustre neolític de La Draga. 
Excavacions de 1999 a 1998. Museu d'Arqueologia de Catalunya (Monografies del Casc 2), Girona, pp 150-165

Sánchez-Quinto F, Schroeder H, Ramírez O, Ávila-Arcos MC, Pybus M, Olalde I, Velázquez AMV, Prada Marcos ME, Vidal Encinas JM, Bertranpetit J, Orlando L, Gilbert MTP, Lalueza-Fox C (2012) Genomic affinities of two 7,000-year-old Iberian hunter-gatherers. Curr Biol 22(16):1494-1499

Schulting RJ (2011) Mesolithic-Neolithic transitions: an isotopic tour through Europe. In: Pinhasi R, Stock J (eds) The bioarchaeology of the transition to agriculture. Wiley-Liss, New York, pp 17-41

Schulting RJ (2013) On the northwestern fringes: earlier Neolithic subsistence in Britain and Ireland as seen through faunal remains and stable isotopes. In: Colledge S, Conolly J, Dobney K, Manning K, Shennan S (eds) The origins and spread of stock-keeping in the near east and Europe. Left Coast Press, Walnut Creek, pp 313-338

Schulting RJ (2018) Dietary shifts at the Mesolithic-Neolithic transition in Europe: an overview of the stable isotope data. In: Lee-Thorp J, Katzenberg MA (eds) The Oxford handbook of the archaeology of diet. Oxford University Press, Oxford

Schulting RJ, Borić D (2017) A tale of two processes of Neolithisation: southeast Europe and Britain/Ireland. In: Bickle P, Cummings V, Hofmann D, Pollard J (eds) Neolithic Europe: essays in honour of professor Alasdair Whittle. Oxbow Books, Oxford, pp 82-104

Schwarcz HP, Schoeninger MJ (1991) Stable isotope analysis in human nutritional ecology. Yearb Phys Anthropol 34:283-321

Sealy J, Johnson M, Richards MP, Nehlich O (2014) Comparison of two methods of extracting bone collagen for stable carbon and nitrogen isotope analysis: comparing whole bone demineralization with gelatinization and ultrafiltration. J Archaeol Sci 47:64-69

Sesma-Sesma J, López-Quintana JC, Mujika JA, Rodanés JM, Vegas JI (2009) El período Calcolítico-Edad del Bronce en el Cantábrico Oriental. In: Medio siglo de Arqueología en el cantábrico oriental y su entorno. Instituto Alavés de Arqueología, Vitoria-Gasteiz, pp $115-200$

Soto DX, Wassenaar LI, Hobson KA, Catalana J (2011) Effects of size and diet on stable hydrogen isotope values $(\delta \mathrm{D})$ in fish: implications for tracing origins of individuals and their food sources. Can J Fish Aquat Sci 68(11):2011-2019

Speth J, Spielmann K (1983) Energy source, protein metabolism and hunter-gatherer subsistence strategies. J Anthropol Archaeol 2:1-31

Sponheimer M, Robinson TF, Cerling TE, Tegland L, Roeder BL, Ayliffe L, Dearing MD, Ehleringer JR (2006) Turnover of stable carbon isotopes in the muscle, liver, and breath $\mathrm{CO} 2$ of alpacas (Lama pacos). Rapid Commun Mass Spec 20(9):1395-1399
Stika HP (2005) Early Neolithic agriculture in Ambrona, province Soria, central Spain. Veg Hist Archaeobotany 40:61-65

Tsutsaya T, Yoneda M (2013) Quantitative reconstruction of weaning ages in archaeological human populations using bone collagen nitrogen isotope ratios and approximate bayesian computation. PLoS One 8(8):e72327. https://doi.org/10.1371/journal.pone.0072327

Ubelaker DH (1989) The estimation of age at death from immature human bone. In: Iscan MY (ed) Age markers in the human skeleton. Charles C. Thomas, Springfield, pp 55-70

Utrilla P, Cava A, Alday A, Baldellou V, Barandiarán I, Mazo O, Montes L (1998) Le passage du Mésolithique au Néolithique ancien dans le Bassin de l'Ebre (Espagne) d'aprés les datations C14. Préhist Eur 12:171-195

Utrilla P, Lorenzo JI, Baldellou V, Sopena MC, Ayuso P (2008) Enterramiento masculino en fosa, cubierto de cantos rodados, en el Neolítico antiguo de la cueva de Chaves. In: Hernández MS, Soler JA, López-Padilla JA (eds) IV Congreso del Neolítico Peninsular (Alicante, 2006), vol II. Museo Arqueológico de Alicante, Alicante, pp 131-140

Villalba-Mouco V, Utrilla P, Laborda R, Lorenzo JI, Martínez-Labarga C, Salazar-García DC (2018a) Reconstruction of human subsistence and husbandry strategies from the Iberian Early Neolithic: a stable isotope approach. Am J Phys Anthropol 167(2):257-271

Villalba-Mouco V, Sarasketa-Gartzia I, Utrilla P, Oms FX, Mazo C, Mendiela S, Cebrià A, Salazar-García DC (2018b) Stable isotope ratio analysis of bone collagen as indicator of different dietary habits and environmental conditions in northeastern Iberia during the 4th and 3rd millennium cal B.C. Archaeol Anthropol Sci

Wood JW, Milner GR, Harpending HC, Weiss KM (1992) The osteological paradox. Curr Anthropol 33:343-370

Zapata L (2000) La recolección de plantas silvestres en la subsistencia mesolítica y neolítica: datos arqueobotánicos del País Vasco. Complutum 11:157-169

Zapata L, Peña-Chocarro L, Perez-Jordá G, Stika HP (2004) Early Neolithic agriculture in the Iberian peninsula. J World Prehist 18: 283-325

Zapata L, Baldellou V, Utrilla P (2008) Bellotas de cronología neolítica para consumo humano en la cueva de Chaves (Bastarás, Huesca). In: Hernández MS, Soler JA, López-Padilla JA (eds) IV Congreso del Neolítico Peninsular (Alicante, 2006), vol II. Museo Arqueológico de Alicante, Alicante, pp 402-410

Publisher's note Springer Nature remains neutral with regard to jurisdictional claims in published maps and institutional affiliations. 